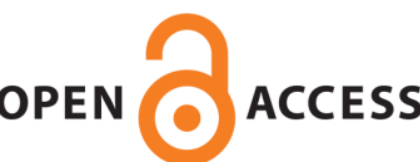

OPEN ACCESS

UWS Academic Portal

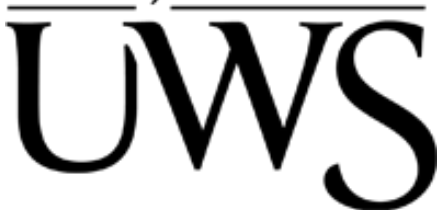

\title{
Quantification and characterization of C-S-H in silica nanoparticles incorporated cementitious system
}

Singh, LP; Zhu, Wenzhong; Howind, Torsten; Sharma, U

Published in:

Cement \& Concrete Composites

DOI:

10.1016/j.cemconcomp.2017.02.004

Published: 01/05/2017

Document Version

Peer reviewed version

Link to publication on the UWS Academic Portal

Citation for published version (APA):

Singh, LP., Zhu, W., Howind, T., \& Sharma, U. (2017). Quantification and characterization of C-S-H in silica nanoparticles incorporated cementitious system. Cement \& Concrete Composites, 79, 106-116.

https://doi.org/10.1016/j.cemconcomp.2017.02.004

\section{General rights}

Copyright and moral rights for the publications made accessible in the UWS Academic Portal are retained by the authors and/or other copyright owners and it is a condition of accessing publications that users recognise and abide by the legal requirements associated with these rights.

Take down policy

If you believe that this document breaches copyright please contact pure@uws.ac.uk providing details, and we will remove access to the work immediately and investigate your claim. 


\section{Accepted Manuscript}

Quantification and characterization of C-S-H in silica nanoparticles incorporated cementitious system

L.P. Singh, W. Zhu, T. Howind, U. Sharma

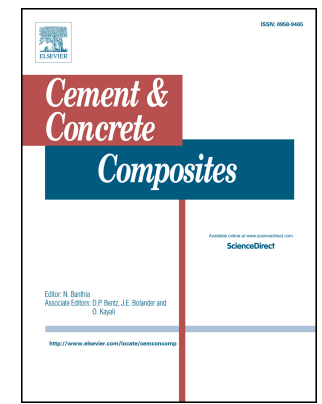

PII:

S0958-9465(16)30207-4

DOI:

10.1016/j.cemconcomp.2017.02.004

Reference: CECO 2780

To appear in: Cement and Concrete Composites

Received Date: 31 May 2016

Revised Date: 2 November 2016

Accepted Date: 14 February 2017

Please cite this article as: L.P. Singh, W. Zhu, T. Howind, U. Sharma, Quantification and characterization of C-S-H in silica nanoparticles incorporated cementitious system, Cement and Concrete Composites (2017), doi: 10.1016/j.cemconcomp.2017.02.004.

This is a PDF file of an unedited manuscript that has been accepted for publication. As a service to our customers we are providing this early version of the manuscript. The manuscript will undergo copyediting, typesetting, and review of the resulting proof before it is published in its final form. Please note that during the production process errors may be discovered which could affect the content, and all legal disclaimers that apply to the journal pertain. 


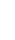

\title{
Quantification and characterization of C-S-H in silica nanoparticles incorporated cementitious system
}

\author{
L.P. Singh ${ }^{\star a}$, W. Zhu ${ }^{b}$, T.Howind $^{\mathrm{b}}$ and U. Sharma ${ }^{\mathrm{a}}$, \\ ${ }^{a}$ CSIR-Central Building Research Institute, India \\ ${ }^{b}$ University of the West of Scotland UK
}

\section{Abstract}

This paper presents the quantification and nanomechanical properties of calcium silicate hydrate $(\mathrm{C}-\mathrm{S}-\mathrm{H})$, formed at early stage hydration of tricalcium silicate (major cement phase) in presence of silica nanoparticles (SNPs). SNPs showed dominant nucleation effect at $8 \mathrm{~h}$ and pozzolanic effect at $24 \mathrm{~h}$ and accelerate the hydration rate $(\sim 83 \%$ at $8 \mathrm{~h}$ and $\sim 51 \%$ at $24 \mathrm{~h}$ ) due to the formation of additional C-S-H nuclei. Further, ${ }^{29} \mathrm{Si}-\mathrm{NMR}$ and FTIR techniques showed the acceleration in polymerization of silicate chain leading to the formation of tobermorite like structure. Formation of polymerized and crystalline C-S-H gel in presence of SNPs increases the percentage of high density C-S-H ( 40\%) and lowers the low density C-S-H ( 52\%) at $24 \mathrm{~h}$ of hydration, as observed in nanoindentation results.

Keywords: Tricalcium silicate, hydration, silica nanoparticles, C-S-H, nanoindentation.

\footnotetext{
${ }^{*}$ Corresponding author. Tel.: + 91- 1332- 283442; fax: +91-1332-272272

E-mail address: Ipsingh@cbri.in; Ipsingh@cbri.res.in
} 


\section{Introduction}

Cement hydration is a complex chemical phenomenon and despite the availability of vast amount of literature on cementitious materials, the structure of $\mathrm{C}-\mathrm{S}-\mathrm{H}$ is of scientific interest [1-3]. Over the past two decades, spectroscopic methods, mainly ${ }^{29}$ Si-nuclear magnetic resonance spectroscopy $\left({ }^{29} \mathrm{Si}-\mathrm{NMR}\right)$, have provided a reasonably clear picture of C-S-H structure at sub-nanometer scale. Solid state ${ }^{29} \mathrm{Si}-\mathrm{NMR}$ studies have established that at early stage of hydration (in fresh paste) C-S-H consists mainly of dimeric silicate chains [4-7]. While after 28 days of hydration, some of the dimers are linked through monomers to form pentamers and then possibly the dimers and pentamers are linked through monomers to form octamers; thus suggesting a 2, 5, 8 , $\ldots \ldots(3 n-1)$ chain length sequence, where $n=1,2,3$, etc. Hence, during the linkage, many of the silicate tetrahedral are missing from chain, therefore, causing imperfection in the both the structure i.e. jennite and 1.4 tobermorite $[8,9]$. The density of the C-S-H layers and inter-layer water exclusive of the gel water was measured using ${ }^{1} \mathrm{H}-\mathrm{NMR}$ [10]. The experiments show that initially (during the first few days) $\mathrm{C}-\mathrm{S}-\mathrm{H}$ grows as a loosely packed assembly of nano crystalline region, wherein the calcium silicate layers are well stacked with inter-layer water. During this period, the amount and size of large capillary pores decreases rapidly and once the size reaches around $10 \mathrm{~nm}$, the number of "gel" pores in the C-S-H no longer increased, even though $\mathrm{CH}$ and $\mathrm{C}-\mathrm{S}-\mathrm{H}$ with interlayer water continue to form. The transition to the formation of this dense C-S-H (without gel pores) leads to an overall increase in the "bulk" density of the C-S-H with time from around $1.8 \mathrm{~g} / \mathrm{cm}^{3}$ at one day to around $2.1 \mathrm{~g} / \mathrm{cm}^{3}$ at one year. Throughout the hydration process the density of the solid nanocrystalline $\mathrm{C}-\mathrm{S}-\mathrm{H}$ remains approximately constant with a slight decrease from $\sim 2.73 \mathrm{~g} / \mathrm{cm}^{3}$ at one day to $2.65 \mathrm{~g} / \mathrm{cm}^{3}$ at one year, due to an increase in the number of layers in the nano crystalline regions [10].

Nanoindentation technique has been widely used for the characterization of $\mathrm{C}-\mathrm{S}-\mathrm{H}$ in hydrated cement paste based on the colloidal model proposed by Jennings [11]. Accordingly, hydration process is completed in early, middle and late periods leading to the formation of two types of C-S-H: low density (LD) and high density (HD). First stage is a period of possibly diffusion-controlled slow reaction, called the "early period," that ends at the time of initial set, secondly, there is a nucleation and growth stage enduring 
until $12-14 \mathrm{~h}$ or may be up to $24 \mathrm{~h}$, called the "middle period" and finally, there is the "late period" or diffusion-controlled stages, for the remaining period of the reaction [12, 13]. Under normal conditions generally LD C-S-H is formed at the middle period, whereas during the later stage, formation of HD C-S-H is predominant [14]. Richardson and Grooves $[15,16]$ have mentioned the presence of two morphologically distinct forms of C-S-H in Transmission Electron Microscopy based on the studies of cement pastes and distinguished between outer product $\mathrm{C}-\mathrm{S}-\mathrm{H}$ and inner product $\mathrm{C}-\mathrm{S}-\mathrm{H}$. Several studies based on nanoindentation of cement pastes have shown that nanoindentation can be used to map mechanical properties of multiphase materials [1720]. The grid-indentation technique was employed to study in detail the two adjacent hydrated cement particles that include unhydrated cement (UC), C-S-H, CH, pores and other hydration products. The modulus of $\mathrm{CH}$ and unhydrated cement grains is reported in the range of $35-40$ and $81-115 \mathrm{GPa}$, respectively. The modulus of $\mathrm{C}-\mathrm{S}-\mathrm{H}$ gel is reported in between 15-40 GPa, wherein, HD C-S-H lies in the range of 28-40GPa, while LD C-S-H have value of 15-30 GPa [21-25]. Kim et al. [26] have quantified the degree of hydration of the cement paste using nanoindentation and compared with that from ${ }^{29} \mathrm{Si}-\mathrm{NMR}$ results. They have reported that a hydration product, which has a relatively high modulus of elasticity over other known hydration products, in the hardened cement paste cured at elevated temperature and pressure. Wei et al. [27] used nanoindentation technique for the determination of degree of hydration in slag blended cementitious system and the results were compared with thermo-gravimetric analysis results and the backscattered electron image analysis methods. They have reported that nanoindentation technique might be an alternative way to quantify degree of hydration of cementitious materials as the results were in good agreement with the TGA and BSE results. Howind et al. [28] studied the intrinsic properties of different hydrate phases and also the possible interaction (or overlapping) of different phases (e.g. C-S-H) using statistical nanoindentation and micro-mechanical property mapping techniques. They have reported that results of the mapping and statistical indentation testing appear to suggest the possible existence of more hydrate phases than the commonly reported LD and HD C-S-H and $\mathrm{CH}$ phases. 
In blended cement, various supplementary materials are used to improve the performance of cementitious system [29, 30]. Recently, silica nanoparticles (SNPs) have received widespread attention in cementitious system due to their high reactivity $[31,32]$. These ultra fine material, not only reduces the calcium leaching but also improves the packing density of C-S-H in harden paste. Mondal et al. [33] reported that incorporation of SNPs significantly alters the proportion of low and high stiffness C-S-H. Singh et al. [34, 35] have studied the early age hydration process of cementitious system in presence of SNPs also quantified the amount hydrated products on the basis of loss on ignition (LOI). They have reported that due to the formation of additional C-S$\mathrm{H}$ seeds, more dense and compact microstructure was formed at $24 \mathrm{~h}$ of hydration in presence of SNPs as these C-S-H seeds accelerate the hydration process and growth hydrated products rapidly in $24 \mathrm{~h}$ of hydration, however, the quantification in acceleration and the stoichiometry of C-S-H in SNPs incorporated cement is still not documented. It will be further interesting to know more about the rate of acceleration and stoichiometry of C-S-H gel formed as it may quantitatively address the durability and sustainability attributes.

\section{Materials and methods}

\subsection{Sample preparation for hydration studies}

For better understanding of hydration chemistry in cementitious system incorporating SNPs at early stage, the main ingredient of cement i.e. tricalcium silicate $\left(\mathrm{C}_{3} \mathrm{~S}\right)$ was used for hydration studies. $\mathrm{C}_{3} \mathrm{~S}$ was prepared and characterized in laboratory using calcium carbonate and silica in a molar ratio $3: 1$ and heated at $\sim 1500^{\circ} \mathrm{C}$, as reported elsewhere in detail [34]. Dispersed powdered SNPs having particle size 30-70 nm were synthesized in laboratory using sodium silicate as a precursor as reported elsewhere in detail [34, 37].

For the hydration studies, $10 \%$ SNPs were added by the weight of $\mathrm{C}_{3} \mathrm{~S}$ and mixed first in dry form. The mixture of $\mathrm{C}_{3} \mathrm{~S}$ and SNPs was hydrated with a w/ $\mathrm{C}_{3} \mathrm{~S}$ ratio 0.4 and hydration process was stopped with acetone at different time intervals. Present research focus is to understand the role of SNPs during early stage kinetic of $\mathrm{C}_{3} \mathrm{~S}$, thus, 
the major studies were focus only up to $24 \mathrm{~h}$ only. However, the hydration process continued upto 1 year for the determination of hydrated products formed on complete hydration. After $24 \mathrm{~h}$ of hydration, the samples were cured in water at room temperature. For the determination of SNPs reactivity in lime paste, samples were prepared by mixing hydraulic lime (calcium hydroxide) (95\% purity) procured by loba chemicals and SNPs in different molar C/S ratio $(0.5,1.0,1.5$ and 2.0) using water to solid ratio of 2.0. The samples were stirrer for 3 min using magnetic stirrer and then the hydrated mixture was stored in a plastic air tight bottle. All the samples were kept in vacuum desiccator to minimize the carbonation rate. For the TGA analysis the paste was washed with acetone and then oven dried at $105^{\circ} \mathrm{C}$.

\subsection{Sample preparation for nanoindentation studies}

$\mathrm{C}_{3} \mathrm{~S}$ paste were prepared by adding $10 \%$ SNPs by the weight of $\mathrm{C}_{3} \mathrm{~S}$ using fixed $w / \mathrm{C}_{3} \mathrm{~S}$ ratio of 0.4 and nanoindentation studied were performed at hydration ages of $24 \mathrm{~h}$. All the paste specimens (typically $10 \times 10 \times 10 \mathrm{~mm}^{3}$ cubes) were kept in the lab $\left(20 \pm 3^{\circ} \mathrm{C}\right)$ in a sealable mould until the targeted hydration age was reached. After demoulding the hydration was stopped by rinsing the paste specimens several times with isopropyl alcohol (as $\mathrm{C}_{3} \mathrm{H}_{8} \mathrm{O}$ replaces water in the paste).

The primary goal of the subsequent surface preparation was to achieve a surface as flat and smooth as possible without possibly losing, dissolving or re-hydrating any of the material phases. Due to the multiphase nature of cement paste, with many different phases varying widely in their Young's modulus (from $E=0 \mathrm{GPa}$ for pores to $E=130$ GPa for unhydrated clinker), it is challenging to achieve a very smooth surface of $R_{\mathrm{q}}<<$ $100 \mathrm{~nm}$ required for reliable nanoindentation testing. As a first step vacuum impregnation with resin (Struers EPOFIX, $E=2-4 \mathrm{GPa}$ ) of the paste samples was performed to avoid the loss of weak phases and to support especially the low strength microstructure during the grinding and polishing procedure. After hardening at room temperature, the excess layer of resin covering the actual paste surface was removed with the aid of abrasive disks, using P1200 silicon carbide emery paper for the final surface approach. Alcohol-based lubricant was used to avoid potential rehydration or 
dissolution of hydration products. Before starting with the surface polishing, all specimens were ultrasonically cleaned using isopropyl alcohol.

The 'long-term - low speed - low contact pressure' surface polishing procedure applied for the nanoindentation specimen preparation consists of 3 subsequently performed polishing steps using diamond particles with sizes of 6,1 or $1 / 4 \mu \mathrm{m}$ with each step lasting for at least 90 minutes. Oil-based diamond sprays were chosen to prevent further hydration or dissolution of sample material and the additional use of oil-based lubricant helped to minimise the build-up of heat during long lasting polishing cycles. Hard and perforated polishing pads were identified to be absolutely essential for successful surface polishing. The hardness of such pads helps to assure that the material is removed evenly (with the highest spots first) while the perforation provides room to accommodate polishing residue, thus assuring a flat and smooth surface finish. Between and during the polishing cycles the progress was closely inspected using a microscope. The right choice of polishing pad, duration, pressure, type and amount of lubricant for every polishing step (from $6 \mu \mathrm{m}$ down to $1 / 4 \mu \mathrm{m}$ ) was found to be crucial for achieving the required surface quality of the specimens.

\subsection{Nanoindentation test setup}

Nanoindentation has been recognised by many researches throughout the world as a very useful technique in the field of micro-structural investigation of materials. It is making contact between an indenter tip of known geometry and mechanical properties and a material sample of interest. This is followed by an application of an increasing load causing the penetration of the indenter into the investigated surface. After reaching a predefined maximum load and typically a short hold period at this value, the load is reduced and the penetration depth decreases due to the elastic recovery of the indented material. During the duration of the experiment the load, $P$, and depth, $h$, values are continuously recorded. The most common method to evaluate hardness and reduced modulus from the load-displacement data obtained with a Berkovich indenter tip was proposed by Oliver and Pharr in 1992 [38] and refined in 2004 [39]. From the obtained data indentation hardness, $H$, and reduced modulus, $E_{r}$, can be calculated as follows: 


$$
\begin{aligned}
& H=\frac{P_{\max }}{A_{c}} \\
& E_{r}=\frac{\sqrt{\pi}}{2} \cdot \frac{S}{\sqrt{A_{c}}}
\end{aligned}
$$

Where $P_{\max }$ is the maximum measured load applied on the indenter and $A c$ is the projected contact area of the indenter tip on the surface and is typically determined as a function of the measured maximum depth, $h_{\max } . S=d P / d h$ is the measured slope of the initial unloading part of the P-h curve. Young's modulus, E, has the following relationship with the determined reduced modulus Er:

$$
\frac{1}{E_{r}}=\frac{1-v^{2}}{E}+\frac{1-v_{i}^{2}}{E_{i}}
$$

Where $E_{\mathrm{i}}$ and $v_{\mathrm{i}}$ are the elastic modulus and Poisson's ratio of the indenter (for diamond: $E_{\mathrm{i}}=1141 \mathrm{GPa}$ and $v_{\mathrm{i}}=0.07$ ), respectively, and $v$ is the Poisson's ratio of the indented material.

Due to low degree of hydration it was opted for a rather large number of 640 indentation test points to assure a minimum of 300 results related to hydrate phases ( $E<50 \mathrm{GPa}$ ). Progressive multistep indentation testing with two load-unload cycles and a maximum load of $1 \mathrm{mN}$ was performed at each of the 640 test points, but only the unloading data of the second cycle ( $\mathrm{hp} \sim 250 \mathrm{~nm}$ ) was used to determine the Young's modulus and hardness values (Fig. 1). Statistical analysis of the obtained bulky array of indentation tests and a subsequent statistical deconvolution of the indentation results is then carried out to determine for each material phase for the corresponding mechanical property values such as Young's modulus and hardness [19]. This approach is known as statistical or grid nanoindentation technique and was first reported in 2004 [20], later more refined method was introduced in 2007 [25] for application on cementitious materials. To assure the coverage of a large and therefore, more representative area the 640 test points were subdivided into 8 batches of $10 \times 8$ indents located along a diagonal line crossing the centre of the specimen (Fig. 2). 
2.4. Determination of the reactivity of silica nanoparticles

To determine the degree of reaction of SNPs in $\mathrm{C}_{3} \mathrm{~S}$ and $\mathrm{CH}$ paste, selective dissolution method was used [39, 40]. $1 \mathrm{~g}$ of the grounded sample was added to a beaker containing $9 \mathrm{~g}$ of picric acid and $60 \mathrm{ml}$ methanol (AR Grade). The mixture was then stirred for 15 min using a magnetic stirrer, then distilled water $(40 \mathrm{ml})$ was added and the mixture was continuously stirred for another $45 \mathrm{~min}$. The solution mixture was transferred into a precisely weighted tube and centrifuged for $30 \mathrm{~min}$. The tube was decanted and again refilled with methanol. This mixture was again centrifuged for 30 min and decanted. The tube was then filled with de-ionized water, centrifuged for $30 \mathrm{~min}$ and the liquid was decanted. This procedure was followed three times and the residue was dried at $110^{\circ} \mathrm{C}$.

Degree of SNPs reaction was determined by the following equation [40]

$$
X(\%)=100 \times\left[1-\frac{X_{1}-0.9\left(X_{2}\right)}{0.1\left(X_{3}\right)}\right]
$$

Where, $\mathrm{X}_{1}$ is weight of sample in $\mathrm{g}$.

$\mathrm{X}_{2}$ is the weight of residue of $1 \mathrm{~g}$ of $\mathrm{C}_{3} \mathrm{~S}$ sample $\left(\mathrm{LOI}\right.$ of $\left.\mathrm{C}_{3} \mathrm{~S}\right)$.

$\mathrm{X}_{3}$ corresponds to residue of $1 \mathrm{~g}$ of SNPs (LOI of SNPs).

\subsection{Determination of degree of hydration}

Degree of hydration was calculated using Portlandite content formed in hydrated samples at different time of intervals. The amount of $\mathrm{CH}$ was calculated directly from the TG curves using the following equations [41, 42]:

$$
\mathrm{CH}(\%)=\mathrm{WL}_{(\mathrm{CH})}(\%) \times \frac{\mathrm{MW}_{(\mathrm{CH})}}{\mathrm{MW}_{(\mathrm{H})}} \quad \mathrm{Eq.5}
$$


Where, $\mathrm{WL}_{(\mathrm{CH})}$ corresponds to weight loss due to dehydration of $\mathrm{CH}$ and $\mathrm{MW}(\mathrm{CH})$, corresponds to molecular weight of $\mathrm{CH}$, while $\mathrm{MW}_{(\mathrm{H})}$ represents molecular weight of water. Further, degree of hydration was calculated using following equation:

$$
\text { Degree of hydration }(\alpha)=\frac{\mathrm{CH}_{(t)}}{\mathrm{CH}_{(\infty)}} \quad \text { Eq. } 6
$$

Where $\mathrm{CH}_{(\mathrm{t})}$ and $\mathrm{CH}_{(\infty)}$ corresponds to $\mathrm{CH}$ content at the time of hydration and $\mathrm{CH}$ content at the complete hydration, respectively.

\subsection{Characteristics techniques}

Influence of SNPs on hydration of $\mathrm{C}_{3} \mathrm{~S}$ at early stage was studied using FTIR (model NEXUS (1100), Thermo Nicolet, FTIR, USA) and TGA (model: Diamond, Perkin Elmer; USA) studies were performed at a heating rate of $5^{\circ} \mathrm{C} / \mathrm{min}$ under nitrogen flow. Statistical nanoindentation testing was performed to determine the micro-mechanical property values, such as Young's modulus and hardness of the individual hydrated phases using an Agilent (now Keysight, USA) Nanolndenter ${ }^{\circledR}$ G200 system fitted with a Berkovich indenter tip.

\section{Results and discussion}

\subsection{Thermogravimetric analysis (TGA)}

For a better understanding of the hydration process in cementitious materials, it is important to quantify the amount of hydration products formed as a function of time. There are no direct methods for the quantification of C-S-H in hydrated paste due to its variable stoichiometry. However, some methods may be used for the quantification of the hydrated products such as quantitative XRD by Rietveld refinement, optical microscopy using point counting, the Bogue method and degree of hydration [43-45]. $\mathrm{DOH}$ is the most widely used method for the quantification of hydrated products in cementitious system. Several authors have reported different methods for the determination of $\mathrm{DOH}$ such as, the amount of $\mathrm{CH}$ in the paste, quantity of the chemically bound water, specific gravity of the paste, fraction of unhydrated cement, 
liberated heat of hydration, strength of the hydrated cement, etc. [46-50]. Non Evaporable Water (NEW) is one the most widely used method to determine the $\mathrm{DOH}$ in hydrated cement paste [49]. However, this method has some limitations with SNPs incorporated samples because in presence of SNPs polymerization in silicate chain accelerated and due to higher polymerization in silicate chain the NEW content reduces down and thus the degree of hydration also decreases [51, 52]. During the polymerization process, combined water in silicate chains can be released, resulting in a decrease of NEW content of the paste [53].

$$
\left(\mathrm{Si}_{2} \mathrm{O}_{7}\right)^{6-}+\left(\mathrm{Si}_{2} \mathrm{O}_{7}\right)^{6-} \longrightarrow\left(\mathrm{Si}_{4} \mathrm{O}_{13}\right)^{10-}+\mathrm{H}_{2} \mathrm{O} \quad \text { Eq. } 7
$$

Another extensively used method to determine the $\mathrm{DOH}$ is the content of portlandite $(\mathrm{CH})$ formed during the hydration process $[54,55]$ using equation 6 . The amount of $\mathrm{CH}$ formed on complete hydration cannot be equal in control and SNPs incorporated samples because $\mathrm{Ca}^{2+}$ are consumed by SNPs and forms additional C-S-H through nucleation and pozzolanic reaction. It is reported that $\sim 70 \% \mathrm{C}_{3} \mathrm{~S}$ hydrates in 28 days and almost completely hydrate in 1 year [56]. The theoretical equation for the complete hydration reported in the literature is as follows [57]:

$$
3 \mathrm{CaO} \cdot \mathrm{SiO}_{2}+(3-x+y) \mathrm{H}_{2} \mathrm{O} \longrightarrow \mathrm{CaO}_{(\mathrm{x})} \cdot \mathrm{SiO}_{2} \cdot \mathrm{H}_{2} \mathrm{O}_{(\mathrm{y})}+(3-\mathrm{x}) \mathrm{Ca}(\mathrm{OH})_{2}
$$

Where, $x$ should be close to 2 , and experimentally it was found that the value of $x$ varies from 1.5 to 2 . The C/S ratio depends on the hydration conditions (bottle, paste), particle size, age and the analytical method employed $[57,58]$. The content of $\mathrm{CH}$ at 1 year of maturity was 1.14 and 0.57 moles for 1 mole of $\mathrm{C}_{3} \mathrm{~S}$ in control and SNPs incorporated samples, respectively. Thus, the complete hydration reaction for the $\mathrm{C}_{3} \mathrm{~S}$ hydration may be as follows:

$$
3 \mathrm{CaO} . \mathrm{SiO}_{2}+5.07 \mathrm{H}_{2} \mathrm{O} \longrightarrow \mathrm{CaO}_{(1.86)} \cdot \mathrm{SiO}_{2} \cdot \mathrm{H}_{2} \mathrm{O}_{(3.96)}+1.14 \mathrm{Ca}(\mathrm{OH})_{2}
$$

While for SNPs incorporated samples, the complete reaction may be as follows:

$$
3 \mathrm{CaO} . \mathrm{SiO}_{2}+5.07 \mathrm{H}_{2} \mathrm{O}+0.38 \mathrm{SiO}_{2} \longrightarrow \mathrm{CaO}_{(2.43)} \cdot \mathrm{SiO}_{(1.38)} \cdot \mathrm{H}_{2} \mathrm{O}_{(4.5)}+0.57 \mathrm{Ca}(\mathrm{OH})_{2}
$$




\section{$\mathrm{C}_{3} \mathrm{~S}$ at $\mathbf{1 h}$}

$3 \mathrm{CaO} . \mathrm{SiO}_{2}+5.07 \mathrm{H}_{2} \mathrm{O}$

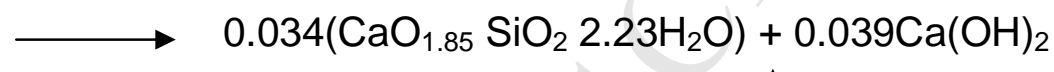$$
+0.966\left(3 \mathrm{CaO}^{2} \mathrm{SiO}_{2}\right)+4.95 \mathrm{Hf} \uparrow
$$

\section{$\mathrm{C}_{3} \mathrm{~S}$ at $3 \mathrm{~h}$}

$3 \mathrm{CaO} . \mathrm{SiO}_{2}+5.07 \mathrm{H}_{2} \mathrm{O}$

$$
\begin{aligned}
\longrightarrow \quad & 0.040\left(\mathrm{CaO}_{1.85} \mathrm{SiO}_{2} 2.01 \mathrm{H}_{2} \mathrm{O}\right)+0.046 \mathrm{Ca}(\mathrm{OH})_{2} \\
& +0.96\left(3 \mathrm{CaO} . \mathrm{SiO}_{2}\right)+4.9 \mathrm{Hf} \uparrow \quad \ldots \ldots . \text { (ii) }
\end{aligned}
$$

\section{$\mathrm{C}_{3} \mathrm{~S}$ at $4 \mathrm{~h}$}

$3 \mathrm{CaO} . \mathrm{SiO}_{2}+5.07 \mathrm{H}_{2} \mathrm{O}$

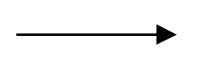

$0.046\left(\mathrm{CaO}_{1.87} \mathrm{SiO}_{2} 1.49 \mathrm{H}_{2} \mathrm{O}\right)+0.052 \mathrm{Ca}(\mathrm{OH})_{2}$

$$
+0.954\left(3 \mathrm{CaO} . \mathrm{SiO}_{2}\right)+4.9 \mathrm{Hf} \uparrow
$$

\section{$\mathrm{C}_{3} \mathrm{~S}$ at $8 \mathrm{~h}$}

$3 \mathrm{CaO} . \mathrm{SiO}_{2}+5.07 \mathrm{H}_{2} \mathrm{O}$

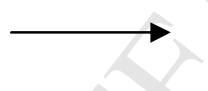

$0.11\left(\mathrm{CaO}_{1.82} \mathrm{SiO}_{2} 1.60 \mathrm{H}_{2} \mathrm{O}\right)+0.13 \mathrm{Ca}(\mathrm{OH})_{2}$ $+0.89\left(3 \mathrm{CaO}^{-\mathrm{SiO}_{2}}\right)+4.76 \mathrm{Hf} \uparrow$

\section{$\mathrm{C}_{3} \mathrm{~S}$ at $15 \mathrm{~h}$}

$3 \mathrm{CaO} . \mathrm{SiO}_{2}+5.07 \mathrm{H}_{2} \mathrm{O}$

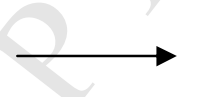

$0.48\left(\mathrm{CaO}_{1.85} \mathrm{SiO}_{2} 1.36 \mathrm{H}_{2} \mathrm{O}\right)+0.55 \mathrm{Ca}(\mathrm{OH})_{2}$ $+0.52\left(3 \mathrm{CaO}^{2} \mathrm{SiO}_{2}\right)+3.87 \mathrm{Hf} \uparrow$

\section{$\mathrm{C}_{3} \mathrm{~S}$ at 24h}

$3 \mathrm{CaO} . \mathrm{SiO}_{2}+5.07 \mathrm{H}_{2} \mathrm{O}$

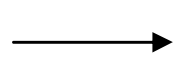

$0.52\left(\mathrm{CaO}_{1.85} \mathrm{SiO}_{2} 1.48 \mathrm{H}_{2} \mathrm{O}\right)+0.60 \mathrm{Ca}(\mathrm{OH})_{2}$

$$
+0.48\left(3 \mathrm{CaO} . \mathrm{SiO}_{2}\right)+3.67 \mathrm{Hf} \uparrow
$$

\section{In the presence of SNPs}

\section{$\mathrm{C}_{3} \mathrm{~S}+\mathbf{1 0} \% \mathrm{SNPs}$ at $\mathbf{1 h}$}

$3 \mathrm{CaO} . \mathrm{SiO}_{2}+0.38 \mathrm{nSiO}_{2}+5.07 \mathrm{H}_{2} \mathrm{O}$
$\longrightarrow \quad 0.040\left(\mathrm{CaO}_{(2.5)} \mathrm{SiO}_{2(6.75)} 3.42 \mathrm{H}_{2} \mathrm{O}\right)+0.15 \mathrm{nSiO}_{2}$ $+0.023 \mathrm{Ca}(\mathrm{OH})_{2}+0.96\left(3 \mathrm{CaO} . \mathrm{SiO}_{2}\right)+4.9 \mathrm{Hf} \uparrow$


$\mathrm{C}_{3} \mathrm{~S}+10 \% \mathrm{SNPs}$ at $3 \mathrm{~h}$

$3 \mathrm{CaO} . \mathrm{SiO}_{2}+0.38 \mathrm{nSiO}_{2}+5.07 \mathrm{H}_{2} \mathrm{O}$
$\longrightarrow \quad 0.085\left(\mathrm{CaO}_{(2.43)} \mathrm{SiO}_{2(3.88)} 1.55 \mathrm{H}_{2} \mathrm{O}\right)+0.13 \mathrm{nSiO}_{2}$ $+0.049 \mathrm{Ca}(\mathrm{OH})_{2}+0.92\left(3 \mathrm{CaO} \cdot \mathrm{SiO}_{2}\right)+4.89 \mathrm{Hf} \uparrow$

\section{$\mathrm{C}_{3} \mathrm{~S}+10 \% \mathrm{SNPs}$ at $4 \mathrm{~h}$}

$3 \mathrm{CaO} . \mathrm{SiO}_{2}+0.38 \mathrm{nSiO}_{2}+5.07 \mathrm{H}_{2} \mathrm{O}$
$\longrightarrow \quad 0.12\left(\mathrm{CaO}_{(2.43)} \mathrm{SiO}_{2(3.33)} 3.14 \mathrm{H}_{2} \mathrm{O}\right)+0.10 \mathrm{nSiO}_{2}$ $+0.068 \mathrm{Ca}(\mathrm{OH})_{2}+0.88\left(3 \mathrm{CaO} \cdot \mathrm{SiO}_{2}\right)+4.6 \mathrm{Hf} \uparrow$

\section{$\mathrm{C}_{3} \mathrm{~S}+10 \% \mathrm{SNPs}$ at $8 \mathrm{~h}$}

$3 \mathrm{CaO} . \mathrm{SiO}_{2}+0.38 \mathrm{nSiO}_{2}+5.07 \mathrm{H}_{2} \mathrm{O}$

$0.65\left(\mathrm{CaO}_{(2.43)} \mathrm{SiO}_{2(1.54)} 1.10 \mathrm{H}_{2} \mathrm{O}\right)+0.03 \mathrm{nSiO}_{2}$ $+0.37 \mathrm{Ca}(\mathrm{OH})_{2}+0.35\left(3 \mathrm{CaO} . \mathrm{SiO}_{2}\right)+3.98 \mathrm{Hf} \uparrow$

\section{$\mathrm{C}_{3} \mathrm{~S}+10 \%$ SNPs at $15 \mathrm{~h}$}

$3 \mathrm{CaO} . \mathrm{SiO}_{2}+0.38 \mathrm{nSiO}_{2}+5.07 \mathrm{H}_{2} \mathrm{O}$

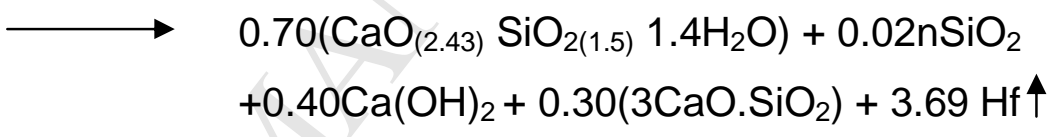

\section{$\mathrm{C}_{3} \mathrm{~S}+10 \%$ SNPs at $24 \mathrm{~h}$}

$3 \mathrm{CaO} . \mathrm{SiO}_{2}+0.38 \mathrm{nSiO}_{2}+5.07 \mathrm{H}_{2} \mathrm{O}$

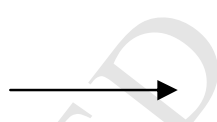

$0.74\left(\mathrm{CaO}_{(2.4)} \mathrm{SiO}_{2(1.5)} 1.62 \mathrm{H}_{2} \mathrm{O}\right)+0.42 \mathrm{Ca}(\mathrm{OH})_{2}$ $+0.26\left(3 \mathrm{CaO}^{-\mathrm{SiO}_{2}}\right)+3.45 \mathrm{Hf} \uparrow$

These results show that addition of SNPs results in the formation of $\mathrm{C}-\mathrm{S}-\mathrm{H}$ exhibiting low $\mathrm{C} / \mathrm{S}$ ratio in the first hour of hydration. Formation of higher amount of $\mathrm{C}-\mathrm{S}-\mathrm{H}$ and lesser $\mathrm{CH}$ content at $1 \mathrm{~h}$ of hydration indicates the lower $\mathrm{Ca}^{2+}$ concentration in pore solution than the control, which accelerates the hydration rate of $\mathrm{C}_{3} \mathrm{~S}$. Reduction in $\mathrm{Ca}^{2+}$ concentration was also observed in our previous study, where we monitored the $\mathrm{Ca}^{2+}$ concentration using Inductive Couple Plasma (ICP), showing that $\mathrm{Ca}^{2+}$ concentration reduces in initial first few minutes of hydration due to formation of additional $\mathrm{C}-\mathrm{S}-\mathrm{H}$ nuclei, which further accelerates the hydration rate (Fig. 3) [34]. As evident from equation (i) and (vii), the acceleration in hydration is $\sim 15 \%$ only at $1 \mathrm{~h}$ of hydration, but it increases up to $83 \%$ at $8 \mathrm{~h}$ of hydration as compared to control showing the nucleation effect of SNPs. In SNPs incorporated samples maximum hydration rate was observed at $8 \mathrm{~h}$ of hydration, while in control sample, this maxima was observed at $15 \mathrm{~h}$ of 
hydration, showing a shift in acceleration period (Fig. 4). These results are in agreement with our earlier findings, where we observed that maximum $\mathrm{Ca}^{2+}$ concentration was observed at 4-6 $\mathrm{h}$ in SNPs incorporated samples, while in case of control sample maximum concentration of $\mathrm{Ca}^{2+}$ was appeared at 10-12 h of hydration (Fig.5) [35]. Fig 6 $(a$ and $b$ ) shows the mass percentage of hydrated and unhydrated products at different time intervals of hydration process. These results show that in control samples hydration rate increases gradually up to $15 \mathrm{~h}$ and then reaches to its steady state level, while in case of SNPs incorporated samples hydration rate increases rapidly up to $8 \mathrm{~h}$ and then steady state level is achieved, showing good agreement with our previous finding regarding shift in acceleration period [35]. Further, the results clearly shows that in SNPs incorporated samples upto $8 \mathrm{~h}$ of hydration, $\mathrm{CH}$ and $\mathrm{C}-\mathrm{S}-\mathrm{H}$ content was found to be higher and $\sim 70 \% \mathrm{C}_{3} \mathrm{~S}$ gets hydrate, while in case of control, less than $20 \%$ of $\mathrm{C}_{3} \mathrm{~S}$ gets hydrate. However at $24 \mathrm{~h}$ of hydration, C-S-H content was higher, while the $\mathrm{CH}$ content was found to be lower in SNPs incorporated samples. These results shows dominant nucleation effect of up to $8 \mathrm{~h}$ and then pozzolanic effect were found to be dominant up to $24 \mathrm{~h}$ of hydration showing good agreements with our previous results [34-36]. Further, it was observed that at $24 \mathrm{~h}$ of hydration $43 \%$ unhydrated $\mathrm{C}_{3} \mathrm{~S}$ was found in control samples, while in SNPs incorporated samples, only $21 \%$ unhydrated $\mathrm{C}_{3} \mathrm{~S}$ was left showing $51 \%$ acceleration in hydration process as compared to control. It was also found that the total reduction in $\mathrm{CH}$ content on complete hydration in presence of SNPs was found to be 1.5 times of SNPs content added with $\mathrm{C}_{3} \mathrm{~S}$.

\subsection{Reactivity of SNPs in lime paste}

Madani et al. [59] studied the pozzolanic reactivity of nanosilica hydrosols in cement and lime paste and have reported that $90 \% \mathrm{CH}$ is consumed within $72 \mathrm{~h}$ of reaction but the amount of SNPs reacted at this time was not mentioned. Pozzolanic reactivity of SNPs with lime within first $24 \mathrm{~h}$ of reaction was evaluated in the mixtures having 0.5 , 1.0, 1.5 and $2.0 \mathrm{C} / \mathrm{S}$ ratio (in mole) and compared. Unreacted SNPs and $\mathrm{CH}$ content was determined using equation 4 and 5 , respectively and water content in C-S-H was experimentally measured from the differences obtained from the mass loss between 105 to $400^{\circ} \mathrm{C}$. The $\mathrm{CaO}$ and $\mathrm{SiO}_{2}$ in $\mathrm{C}-\mathrm{S}-\mathrm{H}$ were adjusted by mass balance between the 
initial and final products of the reactions. These results show that SNPs reactivity at $1 \mathrm{~h}$ increases as the $\mathrm{C} / \mathrm{S}$ ratio is increased due to the availability of $\mathrm{Ca}$. At $1 \mathrm{~h}$ of reaction, only $20 \%$ SNPs is consumed in $0.5 \mathrm{C} / \mathrm{S}$ lime paste sample, while $50 \%$ SNPs reacted in the mixture having a $\mathrm{C} / \mathrm{S}$ ratio 2.0. Fig. 7 shows the reactivity of SNPs and $\mathrm{CH}$ at different time intervals of reaction in various lime paste samples. It clearly indicates that at $24 \mathrm{~h}$ of reaction, in the mixture having low $\mathrm{C} / \mathrm{S}$ ratio $(0.5$ and 1.0$), \mathrm{CH}$ is almost completely consumed, while SNPs reacts more than $85 \%$. However, with $1.5 \mathrm{C} / \mathrm{S}$ ratio mixture, SNPs reacted almost completely and $\sim 90 \% \mathrm{CH}$ is consumed, while in higher $\mathrm{C} / \mathrm{S}$ ratio mixture i.e. 2.0, SNPs completely reacted and $75 \% \mathrm{CH}$ is consumed. Therefore, it may be concluded that almost all SNPs may react within $24 \mathrm{~h}$ if sufficient lime ( 1.5 times) is available. However, this condition may vary in cementitious system 350 due it its heterogeneous nature as the presence of other mineral phases may alter/hinder the reaction kinetics.

\section{At $1 \mathrm{~h}$}

$0.51 \mathrm{Ca}(\mathrm{OH})_{2}+1.035 \mathrm{nSiO}_{2}+11.11 \mathrm{H}_{2} \mathrm{O}$

$\longrightarrow 0.2\left(\mathrm{CaO}_{2.0} \mathrm{SiO}_{2} 1.15 \mathrm{H}_{2} \mathrm{O}\right)+0.11 \mathrm{Ca}(\mathrm{OH})_{2}$ $+0.83 \mathrm{nSiO}_{2}+9.85 \mathrm{Hf} \uparrow$

$0.75 \mathrm{Ca}(\mathrm{OH})_{2}+0.75 \mathrm{nSiO}_{2}+11.11 \mathrm{H}_{2} \mathrm{O}$

$0.17\left(\mathrm{CaO}_{2.76} \mathrm{SiO}_{2} 1.18 \mathrm{H}_{2} \mathrm{O}\right)+0.25 \mathrm{Ca}(\mathrm{OH})_{2}$ $+0.435 \mathrm{nSiO}_{2}+8.98 \mathrm{Hf} \uparrow$

$0.88 \mathrm{Ca}(\mathrm{OH})_{2}+0.585 \mathrm{nSiO}_{2}+11.11 \mathrm{H}_{2} \mathrm{O}$

$0.15\left(\mathrm{CaO}_{3.26} \mathrm{SiO}_{2} 1.15 \mathrm{H}_{2} \mathrm{O}\right)+0.387 \mathrm{Ca}(\mathrm{OH})_{2}$ $+0.57 \mathrm{nSiO}_{2}+9.57 \mathrm{Hf} \uparrow$

$0.96 \mathrm{Ca}(\mathrm{OH})_{2}+0.48 \mathrm{nSiO}_{2}+11.11 \mathrm{H}_{2} \mathrm{O}$

$$
\begin{array}{rrr}
\longrightarrow & 0.23\left(\mathrm{CaO}_{1.65} \mathrm{SiO}_{2} 1.10 \mathrm{H}_{2} \mathrm{O}\right)+0.58 \mathrm{Ca}(\mathrm{OH})_{2} \\
& +0.25 \mathrm{nSiO}_{2}+9.43 \mathrm{Hf} \uparrow
\end{array}
$$

\section{At 24h}

$0.51 \mathrm{Ca}(\mathrm{OH})+1.035 \mathrm{nSiO}_{2}+11.11 \mathrm{H}_{2} \mathrm{O}$

$$
\begin{array}{rrr}
\longrightarrow & 0.88\left(\mathrm{CaO}_{.58} \mathrm{SiO}_{2} 1.81 \mathrm{H}_{2} \mathrm{O}\right)+0.001 \mathrm{Ca}(\mathrm{OH})_{2} \\
+ & 0.15 \mathrm{nSiO}_{2}+9.3 \mathrm{Hf} \uparrow & \ldots \ldots(\mathrm{xvii}) \\
\longrightarrow & 0.6\left(\mathrm{CaO}_{1.13} \mathrm{SiO}_{2} 1.75 \mathrm{H}_{2} \mathrm{O}\right)+0.015 \mathrm{Ca}(\mathrm{OH})_{2} \\
+ & 0.1 \mathrm{nSiO}_{2}+9.34 \mathrm{Hf} \uparrow & \ldots \ldots(\mathrm{xviii}) \\
\longrightarrow & 0.586\left(\mathrm{CaO}_{1.33} \mathrm{SiO}_{2} 1.81 \mathrm{H}_{2} \mathrm{O}\right)+0.097 \mathrm{Ca}(\mathrm{OH})_{2} \\
+ & 0.01 \mathrm{nSiO}_{2}+9.21 \mathrm{Hf} \uparrow & \ldots \ldots(\mathrm{xix}) \\
& 0.48\left(\mathrm{CaO}_{1.5} \mathrm{SiO}_{2} 1.91 \mathrm{H}_{2} \mathrm{O}\right)+0.25 \mathrm{Ca}(\mathrm{OH})_{2} \\
+ & 0.001 \mathrm{nSiO}_{2}+8.95 \mathrm{Hf} \uparrow & \ldots \ldots(\mathrm{xx})
\end{array}
$$

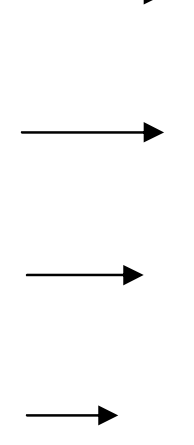$$
0.75 \mathrm{Ca}(\mathrm{OH})_{2}+0.75 \mathrm{nSiO}_{2}+11.11 \mathrm{H}_{2} \mathrm{O}
$$$$
0.88 \mathrm{Ca}(\mathrm{OH})_{2}+0.58 \mathrm{nSiO}_{2}+11.11 \mathrm{H}_{2} \mathrm{O}
$$$$
0.96 \mathrm{Ca}(\mathrm{OH})_{2}+0.48 \mathrm{nSiO}_{2}+11.11 \mathrm{H}_{2} \mathrm{O}
$$ 
3.3. Fourier transform infrared spectroscopy (FTIR) and ${ }^{29}$ Si-Nuclear magnetic resonance $\left({ }^{29} \mathrm{Si}-\mathrm{NMR}\right)$ results

Structural changes occurred in C-S-H gel, during the early stage of hydration, in presence of SNPs were monitored by ${ }^{29} \mathrm{Si}$ NMR technique. ${ }^{29} \mathrm{Si}$ NMR spectrum of anhydrous $\mathrm{C}_{3} \mathrm{~S}$ shows 3 distinct peaks of $\mathrm{SiO}_{4}$ tetrahedral in the range from -67ppm to -78 ppm [60]. At $1 \mathrm{~h}$ and $8 \mathrm{~h}$ of hydration, in control samples, there is a negligible change in the spectra of $\mathrm{C}_{3} \mathrm{~S}$, only the intensity of anhydrous peak reduces showing the progress of hydration (Fig. $8 \mathrm{a}(\mathrm{i})$ and $8 \mathrm{a}(\mathrm{ii})$ ), while in SNPs incorporated samples, a broader resonance is observed at $1 \mathrm{~h}$ of hydration indicating the formation of hydrated layer having amorphous nature (Fig. 8b (i)) [60]. At $8 \mathrm{~h}$ of hydration, relatively small peaks of $Q^{1} \& Q^{2}$ are observed showing the higher rate of polymerization in silicate chain of C-S-H gel in presence of SNPs (Fig. 8b (ii)) [60, 61]. In case of control samples, this polymerization is observed at $15 \mathrm{~h}$ and $24 \mathrm{~h}$ of hydration (Fig. $8 \mathrm{a}$ (iii) and (iv)), while in SNPs incorporated samples, intense $Q^{2}$ and a small peak of $Q^{3}$ is also observed (Fig. $8 \mathrm{~b}$ (iii) and (iv)) [62]. Similar trend of results are observed in FTIR analysis of hydrated sample at $24 \mathrm{~h}$ of hydration. In case of control samples, a shift in $\mathrm{C}_{3} \mathrm{~S}$ peak is observed in Si-O stretching region towards higher frequency with the hydration. At $24 \mathrm{~h}$ of hydration, characteristic peak of $\mathrm{C}_{3} \mathrm{~S}$ at $940 \mathrm{~cm}^{-1}$ shifted to $1100 \mathrm{~cm}^{-1}$ indicating the formation of hydrated products (Fig. 9). While in SNPs incorporated samples, a sharp peak is observed at $968 \mathrm{~cm}^{-1}$ with a shoulder at $1100 \mathrm{~cm}^{-1}$ and a small bump just above $1200 \mathrm{~cm}^{-1}\left(\mathrm{Q}^{3}\right.$ peak) (Fig. 9), which are the characteristic peaks of tobermorite $\left(\mathrm{Ca}_{5} \mathrm{Si}_{6} \mathrm{O}_{16}(\mathrm{OH})_{2} .7 \mathrm{H}_{2} \mathrm{O}\right)$ in $\mathrm{Si}-\mathrm{O}$ stretching region [63-66]. These results indicate that SNPs accelerate the formation of well ordered more polymerized silicate chain.

\subsection{Nanoindentation results}

Recognising the high heterogeneity of hydrated cementitious paste the application of the indentation technique is challenging as it is almost impossible to place indents on a specific material phase with sufficient repeatability. This challenge has been tackled by performing large number of indentation grids on the surface of a heterogeneous material. Statistical analysis of the obtained bulky array of indentation tests and a subsequent statistical deconvolution of the indentation results is then carried out to 
determine the mechanical properties for each material phase. From the obtained result histograms for Young's modulus and hardness the probability density functions are created. Through simultaneous curve-fitting of both types of experimental results with multimodal Gaussian distribution curves, with each curve representing a material phase, using nonlinear least squares method it is then possible to determine the corresponding mechanical property values and phase content (Equation 7).

$$
f(x, y, \sigma)=\frac{1}{\sigma \sqrt{2 \pi}} \exp \left(-\frac{(x-\mu)^{2}}{2 \sigma^{2}}\right)
$$

Where, $\mu$ is the mean value and $\sigma$ is the standard deviation of the distribution curve that is related to the mechanical property of an individual material phase. This approach is known as statistical or grid nanoindentation technique and was first reported in 2004 [20].

For each sample, 640 results were obtained by nanoindentation. The specific mechanical properties for individual hydrated phases (LP C-S-H, LD C-S-H, HD C-S-H, and $\mathrm{CH}$ ) were extracted by statistical analysis/deconvolution technique. In Fig. 10, the statistical histogram plots of the Young's modulus results, fitted with 4 Gaussian distribution curves are presented for control and SNPs incorporated $\mathrm{C}_{3} \mathrm{~S}$ samples at 15 $\mathrm{h}$ and $24 \mathrm{~h}$ of hydration, respectively. For low density ( $2^{\text {nd }}$ peak from the left) and high density C-S-H (3 ${ }^{\text {rd }}$ peak from the left), Young's modulus values of LD C-S-H $\sim 22 \mathrm{GPa}$ and HD C-S-H $\sim 30 \mathrm{GPa}$, respectively were determined from the deconvolution of the statistical nanoindentation data.

The extracted mechanical property values are in good agreement with the results reported in the literature, although those were mainly measured on cementitious systems hydrated for at least 28 days [67,68]. Additionally, results appear to support the theory that the C-S-H structures formed by the hydration of Portland cement and $\mathrm{C}_{3} \mathrm{~S}$ are of the same nature. Early age cementitious paste for all phase distribution plots (Fig. 11) show large quantities of loose-packed (LP C-S-H) and low density C-S-H (LD C-S-H). In general, with progress of hydration a shift from the lower qualities of C-S-H towards higher quantities of high density C-S-H (HD C-S-H) was noticeable. Regarding $\mathrm{C}_{3} \mathrm{~S}$ pastes with SNPs addition, the nanoindentation results on such systems show in 
comparison to their reference materials higher quantities of HD C-S-H. At the same time the contents of LP C-S-H and LD C-S-H were found to be significantly smaller. Additionally, the number of test results with a Young's modulus of less $50 \mathrm{GPa}$, which is expected to be the range for hydration products, was higher thus suggesting a higher degree of hydration. This appears to support well the findings made by TGA.

\section{Conclusion}

Properties of concrete, such as strength, porosity, permeability, durability etc. depend on its main hydrated product i.e. C-S-H. In hydrated paste, it is present in the form of gel like network with variable stoichiometry. Incorporation SNPs not only affects the early stage hydration phenomenon but also the mineralogy and morphology of hydrated products. In the present paper we have quantified the C-S-H gel formed as well as the mineralogical changes occurring in $\mathrm{C}-\mathrm{S}-\mathrm{H}$ gel by the addition of SNPs at early stage of hydration. The major findings are:

1. SNPs accelerates the hydration rate of $\mathrm{C}_{3} \mathrm{~S}$ maximum during acceleration period (4-8 h) showing the nucleation effect of additional C-S-H seeds formed on the surface of SNPs during pre-induction period of hydration. Further, it was observed that $\mathrm{C} / \mathrm{S}$ ratio reduces from 1.86 to 1.6 with the incorporation of SNPs at $24 \mathrm{~h}$ of hydration, showing higher polymerization in silicate chain.

2. SNPs shows dominant nucleation effect at $8 \mathrm{~h}$ of hydration because at this time of hydration the amount of hydrated products was higher ( $85 \%$ additional C-S-H and $\sim 60 \%$ more $\mathrm{CH}$ ) than the control. At $24 \mathrm{~h}$ of hydration, the amount of $\mathrm{C}-\mathrm{S}-\mathrm{H}$ was higher ( $\sim 43 \%)$ and $\mathrm{CH}$ content was lower ( 25\%) than the control, indicating the pozzolanic reactivity of SNPS.

3. Results of mass fraction distribution of hydrated and unhydrated products during early stage hydration process show that $\mathrm{C}_{3} \mathrm{~S}$ hydration rate accelerate $\sim 80 \%$ at 8 h of hydration, while $\sim 51 \%$ at $24 \mathrm{~h}$ of hydration. Further, it was observed that in control sample steady state hydration rate achieve after $15 \mathrm{~h}$ of hydration, while in SNPs incorporated samples, this stage was observed after $8 \mathrm{~h}$ of hydration. 
4. Selective dissolution results indicate that SNPs completely reacted within $24 \mathrm{~h}$ of hydration and it was evaluated experimentally that 0.38 moles of SNPs consumed 0.57 moles of $\mathrm{CH}$ which are 1.5 times of SNPs content.

5. Similar results were observed in SNPs and lime paste samples. These results show that SNPs reactivity increase with $\mathrm{C} / \mathrm{S}$ ratio. At $24 \mathrm{~h}$ of reaction in lower $\mathrm{C} / \mathrm{S}$ ratio $(0.5$ and 1.0$) \sim 83 \%$ SNPs is reacted while with high $\mathrm{C} / \mathrm{S}$ ratio mixture i.e. 1.5 , SNPs reacted almost completely

6. SNPs accelerate the polymerization of silicate chain in $\mathrm{C}-\mathrm{S}-\mathrm{H}$ gel (presence of intense $Q^{2}$ peak and small $Q^{3}$ peak) which leads to the formation of tobermorite like structure (presence of four characteristics peak in Si-O stretching region) at $24 \mathrm{~h}$ of hydration.

7. Nanoindentation results clearly show that SNPs not only accelerate the hydration rate but also improved the packing density of C-S-H particles. At $24 \mathrm{~h}$ of hydration, in SNPs incorporated samples LD C-S-H reduces $\sim 52 \%$ while HD C$\mathrm{S}-\mathrm{H}$ content is increased by $\sim 40 \%$ compare to pure $\mathrm{C}_{3} \mathrm{~S}$ paste indicating the formation of more compact and dense microstrucrure.

Therefore, it is evident from the experimental results that addition of SNPs accelerates the hydration rate at early age (within $24 \mathrm{~h}$ of hydration) and helps to promote the formation of high density (HD) C-S-H.

\section{Acknowledgement:}

Financial support received from CSIR-Central Building Research Institute, Rorrkee, India is gratefully acknowledged. Authors are thankful to UKIERI, as this research is the part of INDO-UK collaboration activity. Author (U. Sharma) is thankful to AcSIR and UGC New Delhi.

\section{References.}

1. L. Zhang, Z. Li, and Z. Lin, The structure of silicate ions in C-S-H discussed from chemical composition, Adv. Cem. Res. 24, (2012), 263-281.

2. J. Ulm, Concrete innovation potential: from atoms to green infrastructure. Beton Stahlbetonbau 107(2012), 504-509. 
3. R.J.M. Pellenq, et al. A realistic molecular model of cement hydrates. Proc. Natl Acad. Sci. 106(2009) 16102-16107.

4. J.J. Beaudoin, L. Rakia and R. Alizadeh $A{ }^{29}$ Si MAS NMR study of modified CS-H nanostructures. Cem. Concr. Res. 31(8) (2009): 585-590.

5. X. Pardal, F. Brunet, T. Charpentier, I. Pochard and A. Nonat, Al-27 and ${ }^{29} \mathrm{Si}$ solid-state NMR characterization of calcium-aluminosilicate-hydrate, Inorg. Chem. 51 (2012) 1827-1836.

6. S. Chatterji, "Comment on 'Mesostructure of calcium silicate hydrate (C-S-H) gels in portland cement paste: short-range ordering, nanocrystallinity, and local compositional order'," J. Am. Ceram. Soc., 80 (1997) 2959-60.

7. X. Cong and R. J. Kirkpatrick, ${ }^{29} \mathrm{Si}$ and ${ }^{17} \mathrm{O}-\mathrm{NMR}$ investigation of the structure of some crystalline calcium silicate hydrates. Adv. Cem. Based. Mater., 3 (1996) 133-143.

8. H.F. Taylor, Proposed structure for calcium silicate hydrate gel, J. Am. Ceram. Soc. 69 (1986) 464-467.

9. E. Bonaccorsi, S. Merlino and H.F.W. Taylor, The crystal structure of jennite, $\mathrm{Ca}_{9} \mathrm{Si}_{6} \mathrm{O}_{18}(\mathrm{OH})_{6} .8 \mathrm{H}_{2} \mathrm{O}$, Cem. Concr. Res. 34 (2004) 1481-1488.

10. A.C.A. Muller, K.L. Scrivener, A. M. Gajewicz and P.J. McDonald, The densification of C-S-H measured by ${ }^{1} \mathrm{H}-\mathrm{NMR}$ relaxometry, J. Phys. Chem. C, 117 (2013) 403-412.

11. H.M. Jennings, A model for the microstructure of calcium silicate hydrate in cement paste, Cem. Concr. Res. 30(2000) 101-16.

12. A.J. Allen and J.J. Thomas, Analysis of C-S-H gel and cement paste by smallangle neutron scattering. Cem. Concr. Res. 37(3) (2007): 319-324.

13. P.D. Tennis and H.M. Jennings, A model for two types of C-S-H in the microstructure of Portland cement pastes. Cem Concr Res. 30 (2000) 855-63.

14. A.J. Allen, J.J. Thomas and H.M. Jennings, Composition and density of nanoscale calcium-silicate-hydrate in cement. Nat. Mater. 6 (2007) 311-316.

15. I.G. Richardson and G.W. Groves, Microstructure and microanalysis of hardened cement pastes involving round granulated blast-furnace slag, J. Mater. Sci. 27(1992) 6204. 
16. I. G. Richardson and G. W. Groves, The structure of the calcium silicate hydrate phases present in hardened pastes of white Portland cement/blast-furnace slag blends, J. Mater. Sci. 32 (1997) 4793-4802.

17.P. Acker, Micromechanical analysis of creep and shrinkage mechanisms. creep, shrinkage and durability mechanics of concrete and other quasi-brittle materials, Elservier, London, UK, 2001.

18.P. Mondal, S.P. Shah, and L. Marks, A reliable technique to determine the local mechanical properties at the nanoscale for cementitious materials. Cem. Concr. Res., 37 (2007) 1440-1444.

19.T. Howind, J. Hughes, and W. Zhu, Mapping of Mechanical Properties of Cement-Based Materials at Micro/Nano-Scale. Jour. Innov. Eng. 2(1) (2014).

20.G. Constantinides and F.J. Ulm, The effect of two types of C-S-H on the elasticity of cement-based materials: results from nanoindentation and micromechanical modeling. Cem. Concr. Res. 34 (2004), 67-80.

21.K. Velez, S. Maximilien and D. Damidot, Determination of nanoindentation of elastic modulus and hardness of pure constituents of Portland cement clinker. Cem. Concr. Res., 31(2001) 555-561.

22.R. Alizadeh and J.J. Beaudoin, Mechanical properties of calcium silicate hydrates, Mater. Struct. 44 (2011) 13-28.

23.P. Trtik, B. Munch and P. Lura, A critical examination of statistical nanoindentation on model materials and hardened cement pastes based on virtual experiments. Cem. Concr. Compos. 31(2009) 705-714.

24.D. Davydov, M.S. Jira and L. Kopecky, Critical aspect of nano-indentation technique in application to hardened cement paste. Cem Concr Res 41(2011) 20-29.

25. M.J. DeJong and F.J. Ulm, The nanogranular nature of C-S-H, J. Mech. Phys. Solids. 55 (2007) 64-90.

26.D. M.J. Jong, and F.J. Ulm, The nanogranular behavior of C-S-H at elevated temperatures (up to $700{ }^{\circ} \mathrm{C}$ ). Cem. Concr. Res. 37(2007) 1-12. 
27.J.J. Kim, M.K. Rahman and M.M.R. Taha, Examining microstructural composition of hardened cement paste cured under high temperature and pressure using nanoindentation and ${ }^{29}$ Si MAS NMR, Appl. Nanosci. 2 (2012)445-456

28. Y. Wei, X. Gao and S. Liang, Nanoindentation-based study of the micromechanical properties, structure, and hydration degree of slag-blended cementitious materials, J. Mater. Sci. 51 (2016) 3349-3361

29. I.G. Richardson, Tobermorite/jennite-and tobermorite/calcium hydroxide-based models for the structure of $\mathrm{C}-\mathrm{S}-\mathrm{H}$ : applicability to hardened pastes of tricalcium silicate,[beta]-dicalcium silicate, Portland cement, and blends of Portland cement with blast-furnace slag, metakaolin, or silica fume, Cem. Concr. Res. 34 (2004) 1733-1777.

30.W.A. Gutteridge and J.A. Dalziel, Filler cement: the effect of the secondary component on the hydration of Portland cement: part I. A fine non-hydraulic filler, Cem. Concr. Res. 20 (1990) 778-782.

31. M. Berra, F. Carassiti, T. Mangialardi, A.E. Paolini and M. Sebastiani, Effects of nanosilica addition on workability and compressive strength of Portland cement pastes, Constr. Build. Mater. 35 (2012) 666-675.

32. F. Kontoleontos, P.E. Tsakiridis, A. Marinos, V. Kaloidas and M. Katsioti, Influence of colloidal nanosilica on ultrafine cement hydration: Physicochemical and microstructural characterization, Constr. Build. Mater. 35 (2012) 34-360.

33. P. Mondal, S. P. Shah, L. D. Marks and J. J. Gaitero, Comparative study of the effects of microsilica and nanosilica in concrete. Transp. Res. Rec. (2010) 6-9.

34. L.P. Singh, S.K. Bhattacharyya, S.P. Shah, G. Mishra, S. Ahalawat and U. Sharma, Studies on early stage hydration of tricalcium silicate incorporating silica nanoparticles: Part I, Constr. Build. Mater. 74 (2015) 278-286.

35. L.P. Singh, S.K. Bhattacharyya, S.P. Shah, G. Mishra, S. Ahalawat and U. Sharma, Studies on early stage hydration of tricalcium silicate incorporating silica nanoparticles: Part II, Constr. Build. Mater. 102 (2016) 943-949.

36. L.P. Singh, D. Ali, U. Sharma, Studies on optimization of silica nanoparticles dosage in cementitious system, Cement. Concrete. Comp. 70 (2016) 60-68. 
37.L. P. Singh, A. Goel, S. K. Bhattachharyya, S. Ahalawat, U. Sharma, and G. Mishra, Effect of Morphology and Dispersibility of Silica Nanoparticles on the Mechanical Behaviour of Cement Mortar, International Journal of Concrete Structures and Materials,9 (2015) 207-217.

38.W.C. Oliver and G.M. Pharr, An improved technique for determining hardness and elastic modulus using load and displacement sensing indentation experiments, J. Mater. Res., 7(1992) 1564-1583.

39. W.C. Oliver and G.M. Pharr, Measurement of hardness and elastic modulus by instrumented indentation: Advances in understanding and refinements to methodology. J. Mater. Res., 19(2004) 3-20.

40.S. Li, D.M. Roy and Amitabha, Quantitative determination of pozzolanas in hydrated systems of cement or $\mathrm{Ca}(\mathrm{OH})_{2}$ with fly ash or siliCa2+fume, Cem. Con. Res. 15 (1985) 1079-1086.

41.L. Lam, Y.L. Wong and C.S. Poon, Degree of hydration and gel/space ratio of high-volume fly ash/cement systems, Cem. Concr. Res. 30 (2000) 747-756

42. Y. Aono, F. Matsushita, S. Shabita and Y. Hama, Nano structural changes of C$\mathrm{S}-\mathrm{H}$ in harden cement paste during drying at $50^{\circ} \mathrm{C}$, J. Adv. Con. Tech. 5 (2007) 313-323.

43.J. Jain and N. Neithalath, Analysis of calcium leaching behaviour of plain and modified cement pastes in pure water, Cem. Concr. Comp., 31 (2009) 176-185.

44. G. Walenta and T. Fullmann (2004) Advances in quantitative XRD analysis for clinker, cements, and cementitious additions. Powder Diffraction 19(1): 40-44.

45.K.L. Scrivener, T. Fullmann, E. Gallucci, G. Walenta and E. Bermejo, Quantitative study of Portland cement hydration by X-ray diffraction/Rietveld analysis and independent methods. Cem. Concr. Res., 34 (2004) 1541-1547.

46. K.L. Scrivener, Backscattered electron imaging of cementitious microstructures: understanding and quantification, Cem. Concr. Comp. 26(2004) 935945.

47.M.B. Haha, K.D. Weerdt and B. Lothenbach, Quantification of the degree of reaction of fly ash. Cem. Concr. Res. 40(2010) 1620-1629. 
48. S.O. Ekolu, Simple hydration equation as a method for estimating water-cement ratio in old concrete, Concrete Repair, Rehabilitation and Retrofitting II Alexander et al (eds) @ 2009 Taylor \& Francis Group, London, ISBN 978-0-41546850-3.

49. W. Jiang, G.D. Schutter, Y. Yuan, Degree of hydration based prediction of early age basic creep and creep recovery of blended concrete, Cem. Concr. Comp. 48 (2014) 83-90.

50. I. Pane and W. Hansen, Investigation of blended cement hydration by isothermal calorimetry and thermal analysis, Cement and Concrete Research 35 (2005) 1155- 1164.

51. L. P. Singh, A. Geol, S. K. Bhattacharyya, U. Sharma and G. Mishra, Hydration studies of cementitious system using silica nanoparticles, J. Adv. Concr. Technol., 13 (2015) 345-354.

52.P. Hou, S. Kawashima, D. Kong, D. J. Corr, J. Qian and S. P. Shah, Modification effects of colloidal nanoSiO ${ }_{2}$ on cement hydration and its gel property, Comp: Part B. 45 (2013) 440-448

53. D. Kong, X. Du, S. Wei, H. Zhang, Y. Yang and S. P. Shah. Influence of nanosilica agglomeration on microstructure and properties of the hardened cement based materials, Constr. Build. Mater. 37 (2012) 707-715.

54.C. Huang and R.F. Feldman, Hydration reactions in Portland cement-silica fume blends. Cem Concr Res 15 (1985) 585-92.

55.S. Goñi, F. Puertas, M.S. Hernández, M. Palacios, A. Guerrero, J. S. Dolado, B. Zanga and F. Baroni, Quantitative study of hydration of $\mathrm{C}_{3} \mathrm{~S}$ and $\mathrm{C}_{2} \mathrm{~S}$ by thermal analysis, J. Therm. Anal. Calorim., 102 (2010) 965-973.

56. H.F.W. Taylor, Cement Chemistry (2nd ed.), Thomas Telford, London, U.K., 1997.

57.H.J.H. Brouwers, The work of Powers and Brownyard revisited: Part 1, Cem. Concr. Res. 34 (2004) 1697-1716.

58.J.F. Young, W. Hansen, Volume relationships for C-S-H formation based on hydration stoichiometries, Mater. Res. Soc. Symp. Proc. 85 (1987) 313- 322. 
59. H. Madani, A. Bagheri, T. Parhizkar, The pozzolanic reactivity of monodispersed nanosilica hydrosols and their influence on the hydration characteristics of Portland cement, Cem. Concr. Res. 42 (2012) 1563-1570

60.F. Bellmann, D. Damidot, B. Möser, J. Skibsted, Improved evidence for the existence of an intermediate phase during hydration of tricalcium silicate, Cem. Concr. Res. 40 (2010) 875-884.

61.C. M. Dobson, D.G.C. Goberdhan, J.D.F. Ramsay and S.A. Rodger, ${ }^{29}$ Si MAS NMR study of the hydration of tricalcium silicate in the presence of finely divided silica, J. Mater. Sci. 23 (1988) 4108-4114.

62. J.J. Beaudoin, L. Raki and R. Alizadeh, A ${ }^{29} \mathrm{Si}-$ MAS NMR study of modified CS-H nanostructures, Cem. Concr. Comp. 31 (2009) 585-590

63. R. YImén, U. Jäglid, B. M. Steenari and I. Panas, Early hydration and setting of Portland cement monitored by IR, SEM and Vicat techniques, Cem. Concr. Res. 39 (2009) 433-439.

64. L. Fernandez, C. Alonso, A. Hidalgo and C. Andrade, The role of magnesium during the hydration of $\mathrm{C}_{3} \mathrm{~S}$ and $\mathrm{C}-\mathrm{S}-\mathrm{H}$ formation. Scanning electron microscopy and mid-infrared studies, Adv. Cem. Res. 17 (2005) 9-21.

65.J. Bjornstrom, Accelerating effects of colloidal nano-silica for beneficial calciumsilicate-hydrate formation in cement, Chem. Phys. Lett. 392 (2004) 242-248.

66.P. Yu, R.J. Kirkpatrick, B. Poe, P.F. McMillan and X. Cong, Structure of calcium silicate hydrate (C-S-H): near-, mid-, and far infrared spectroscopy, J. Am. Ceram. Soc. 82 (3) (1999) 742-748.

67.W. Zhu John J. Hughes, N. Bicanic, C.J. Pearce, Nanoindentation mapping of mechanical properties of cement paste and natural rocks. Mater. Charact, 58 (2007) 1189-1198.

68. T. Howind, Micro-mechanical properties of cement based material. University of the West of Scotland 2014. 


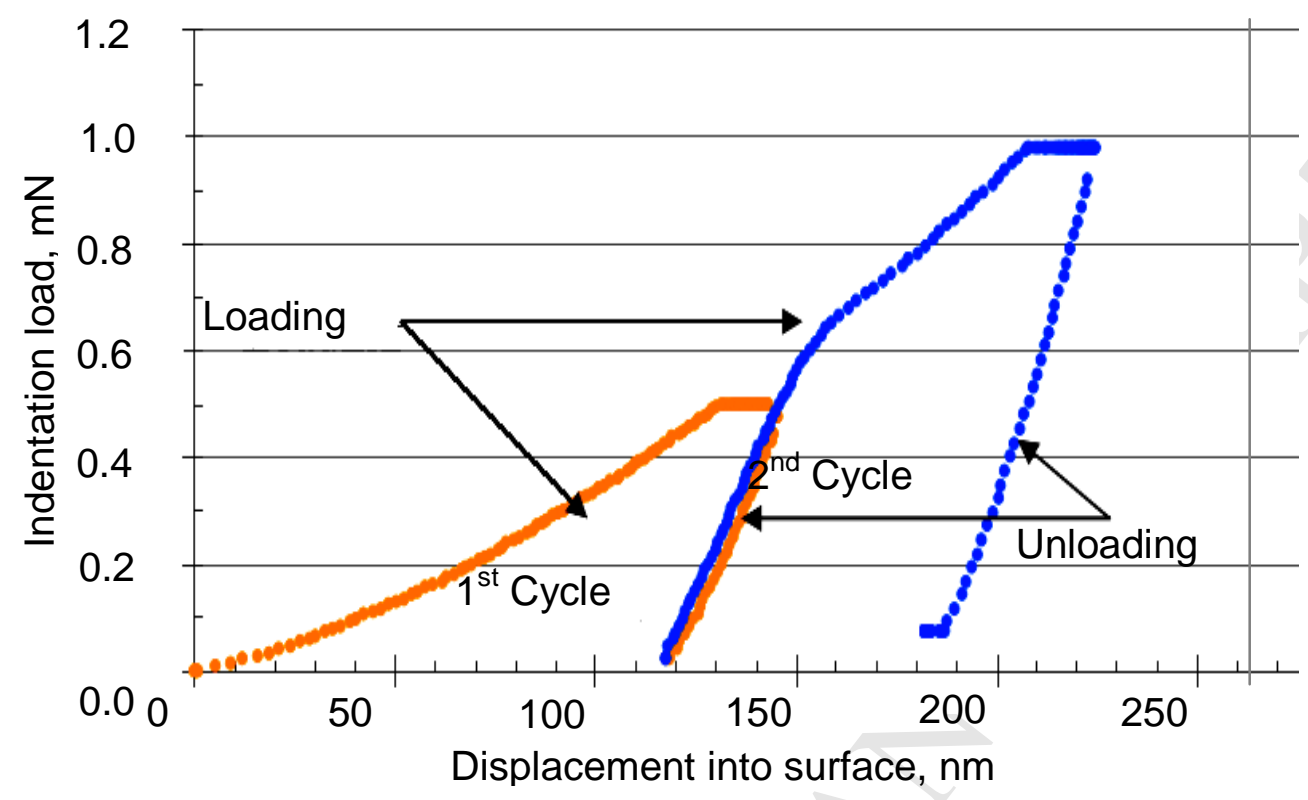

Fig. 1. Typical P - h curve of a two-step nanoindentation test.

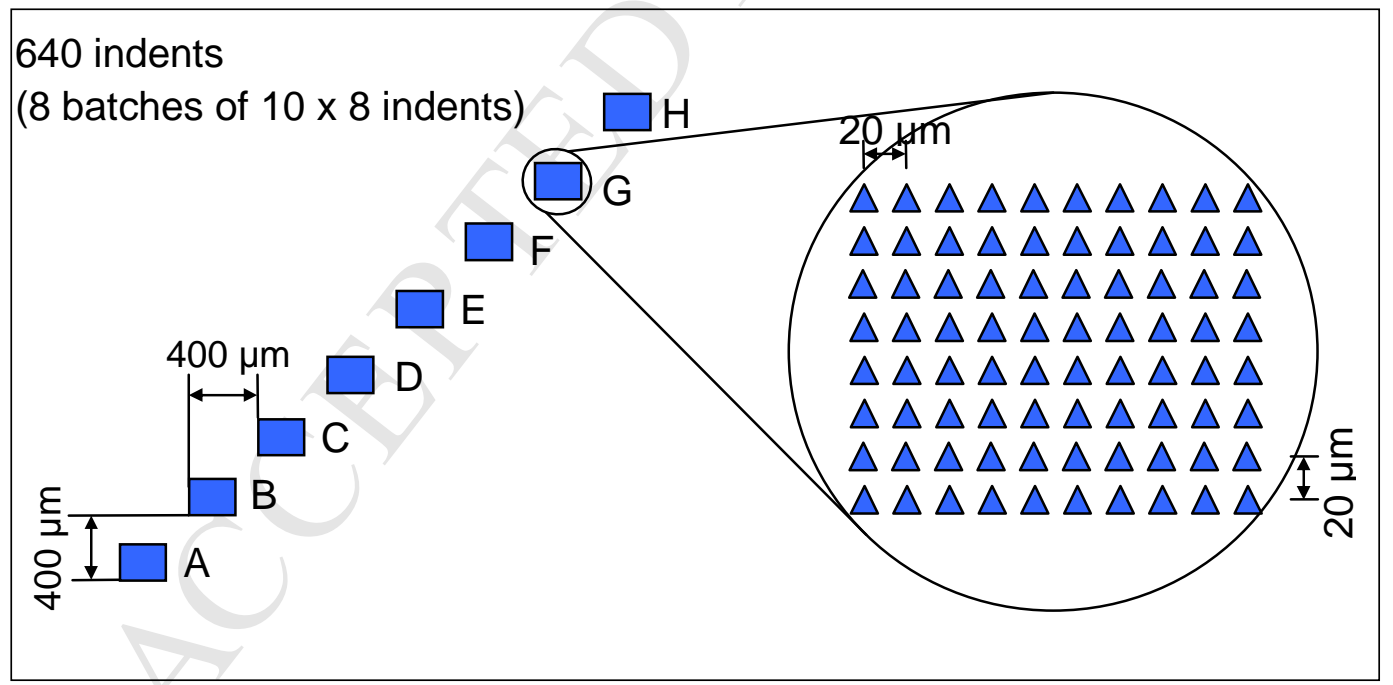

Fig. 2. Test points arrangement for the grid nanoindentation testing. 


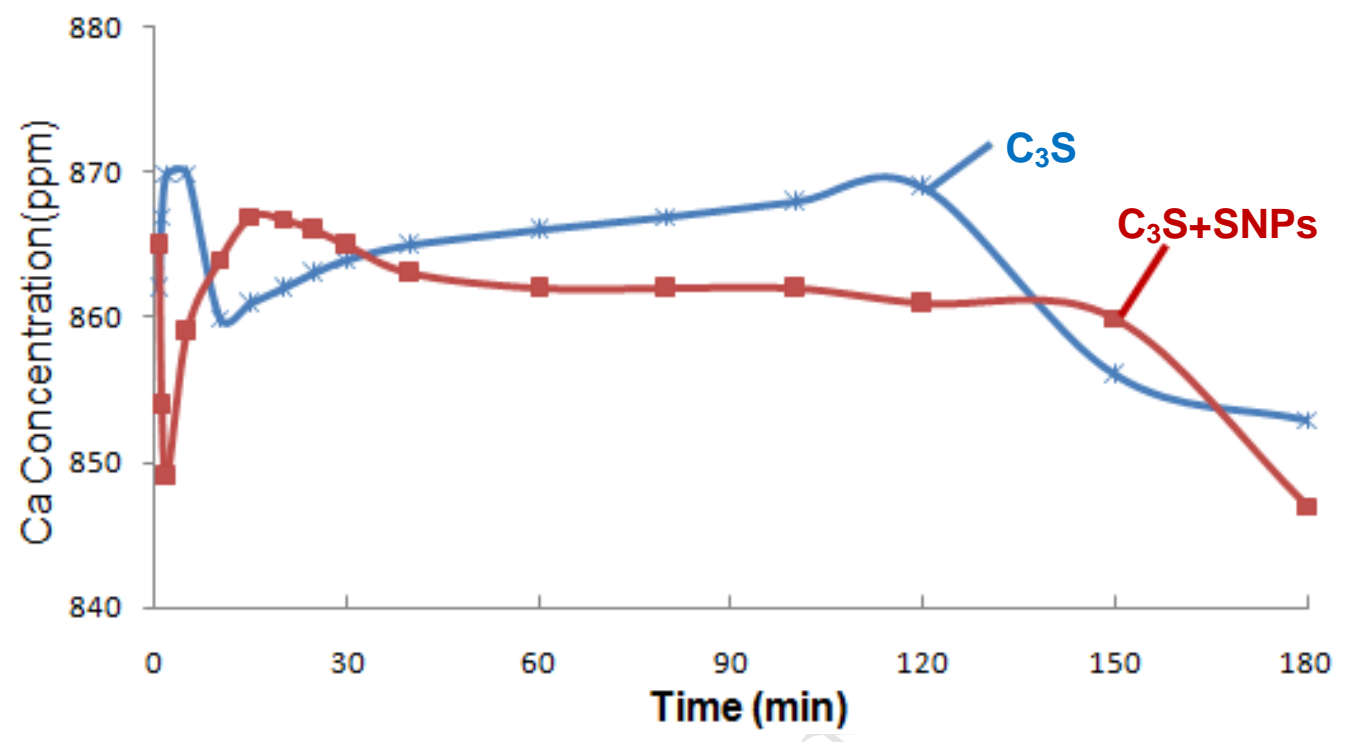

Fig. 3. Ca concentration in pure and SNPs incorporated $\mathrm{C}_{3} \mathrm{~S}$ [34].

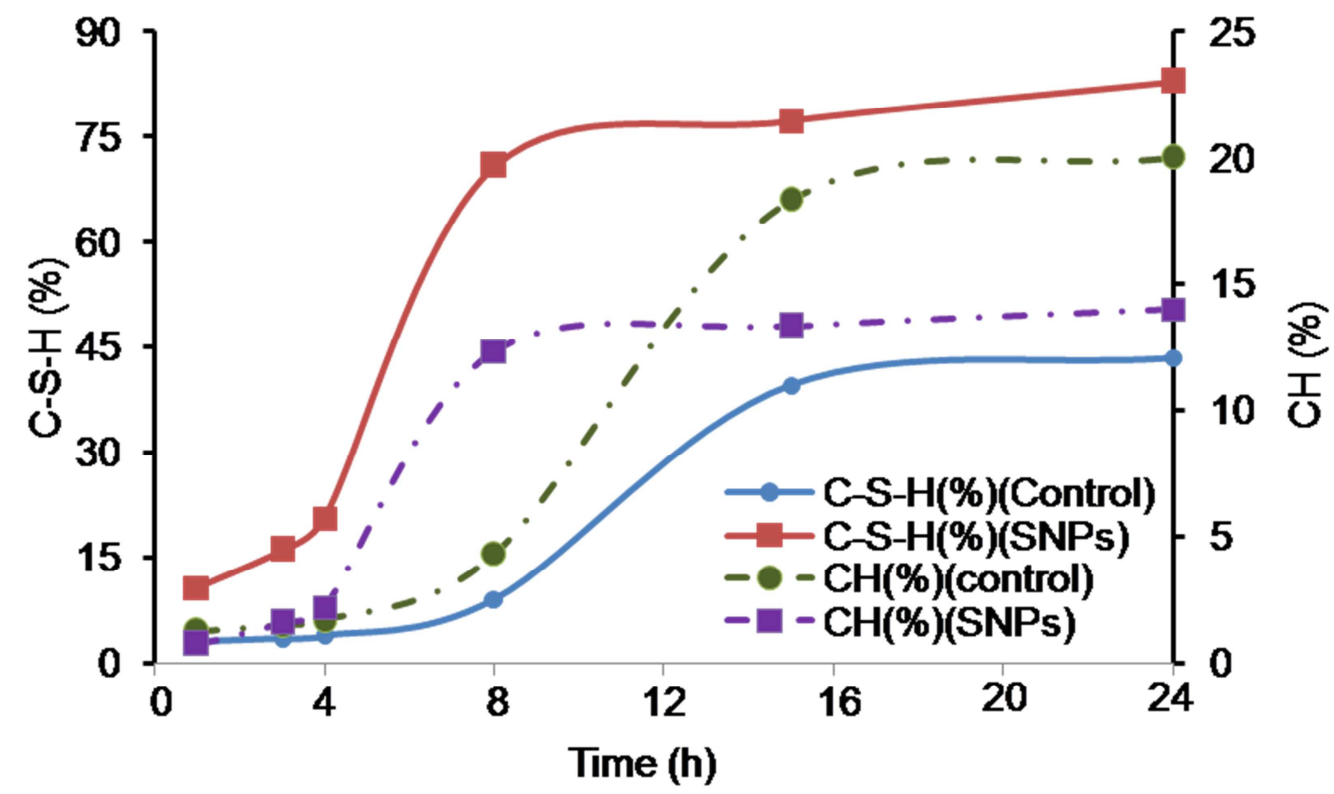

Fig. 4. Percentage of $\mathrm{C}-\mathrm{S}-\mathrm{H}$ and $\mathrm{CH}$ formed during hydration of $\mathrm{C}_{3} \mathrm{~S}$ and SNPS incorporated $\mathrm{C}_{3} \mathrm{~S}$ samples at different time intervals 


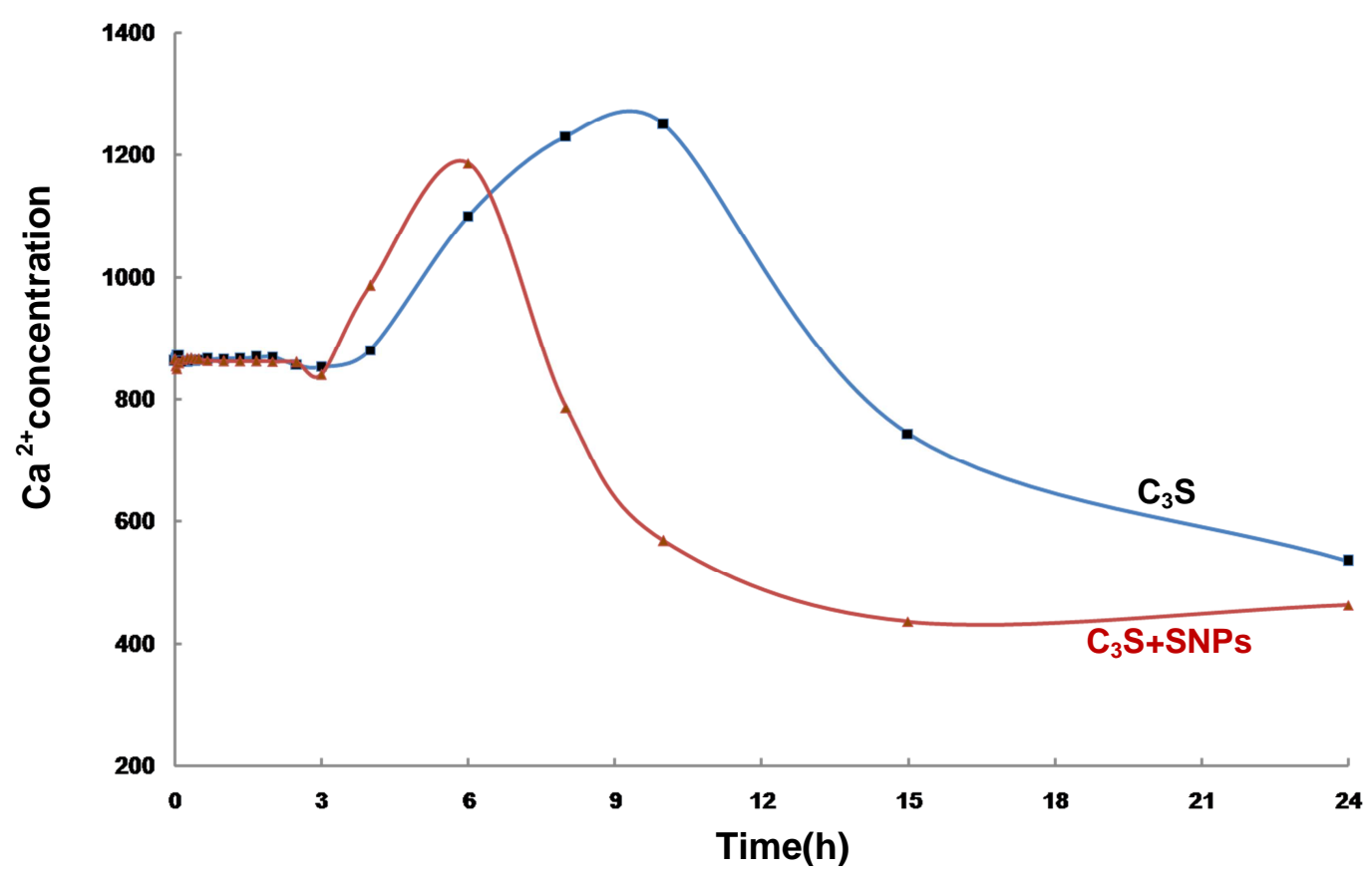

Fig. 5. $\mathrm{Ca}^{2+}$ concentration in pure and SNPs incorporated $\mathrm{C}_{3} \mathrm{~S}$ at different time intervals [35].
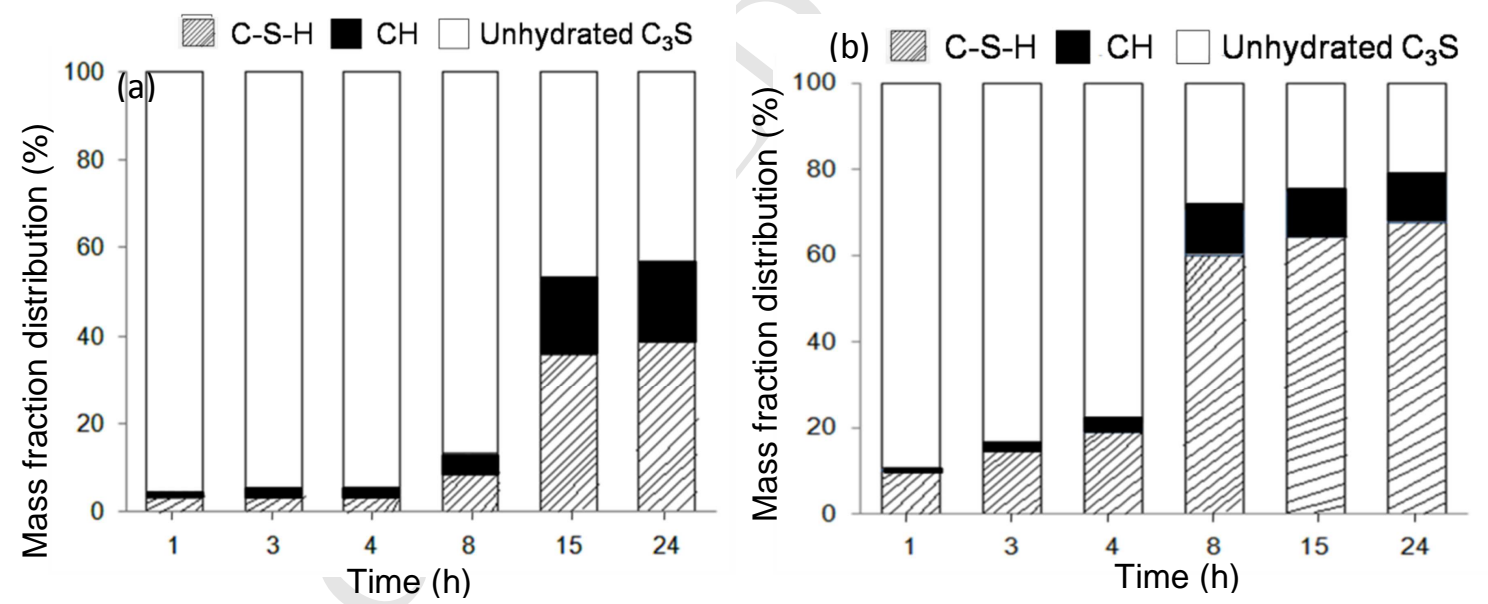

Fig. 6. Hydrated and unhydrated fractions of $\mathrm{C}_{3} \mathrm{~S}$ (a) and $\mathrm{C}_{3} \mathrm{~S}$ incorporating SNPs (b) showing accelerated hydration reaction. 


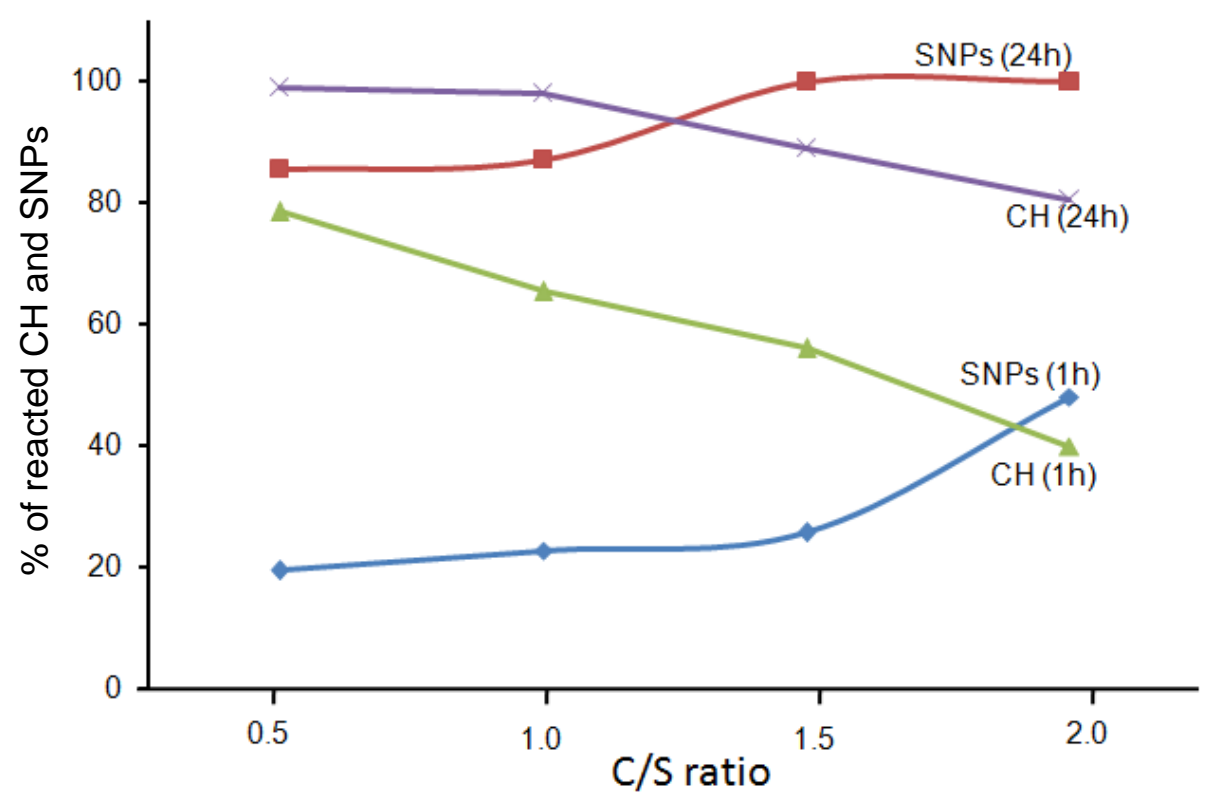

Fig. 7. Percentage of reacted $\mathrm{CH}$ and SNPs in hydrated lime at different time intervals
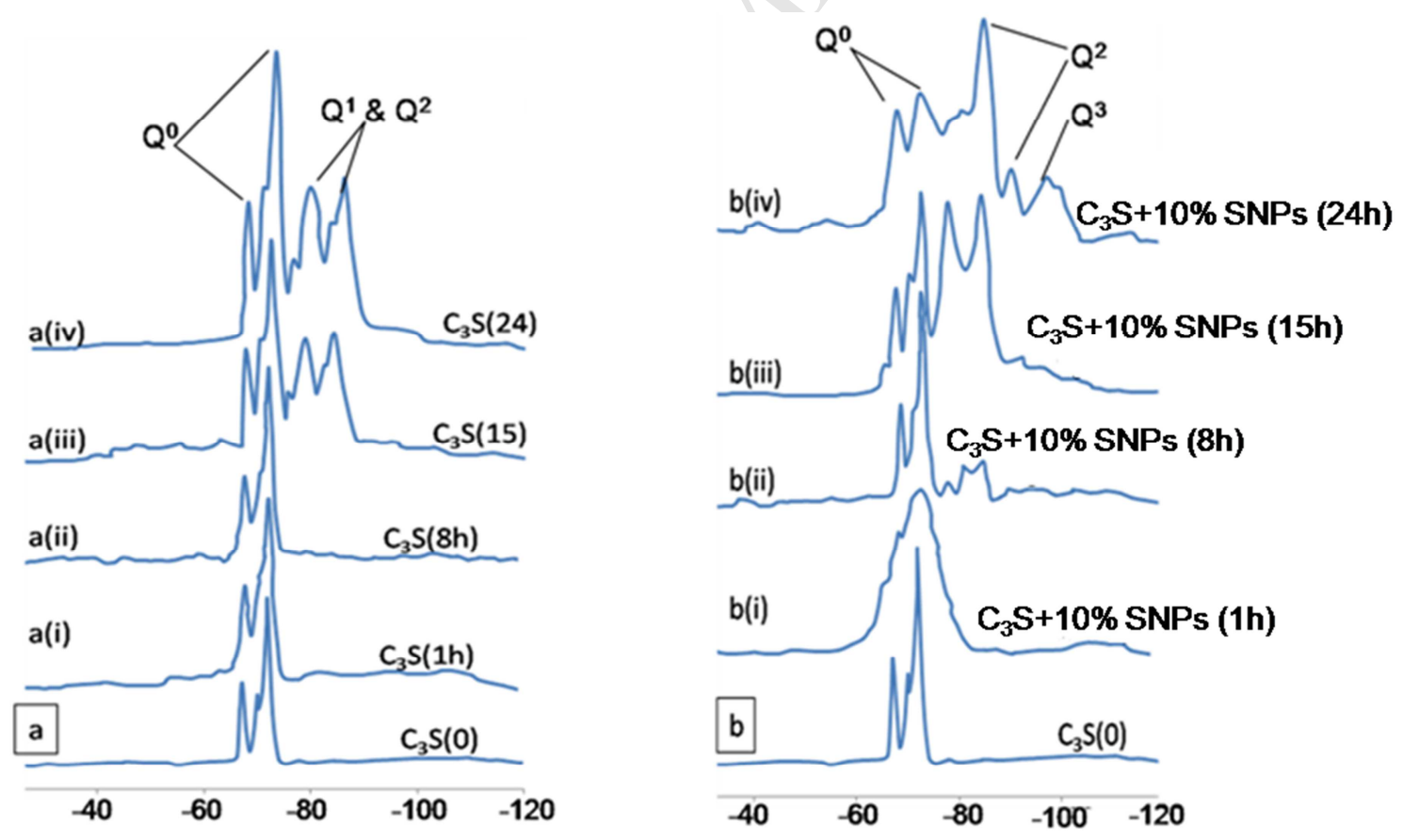

Fig.8. ${ }^{29} \mathrm{Si}$ mass NMR of hydrated $\mathrm{C}_{3} \mathrm{~S}(\mathrm{a})$ and $\mathrm{C}_{3} \mathrm{~S}+10 \% \mathrm{SNPs}(\mathrm{b})$ at different time intervals 


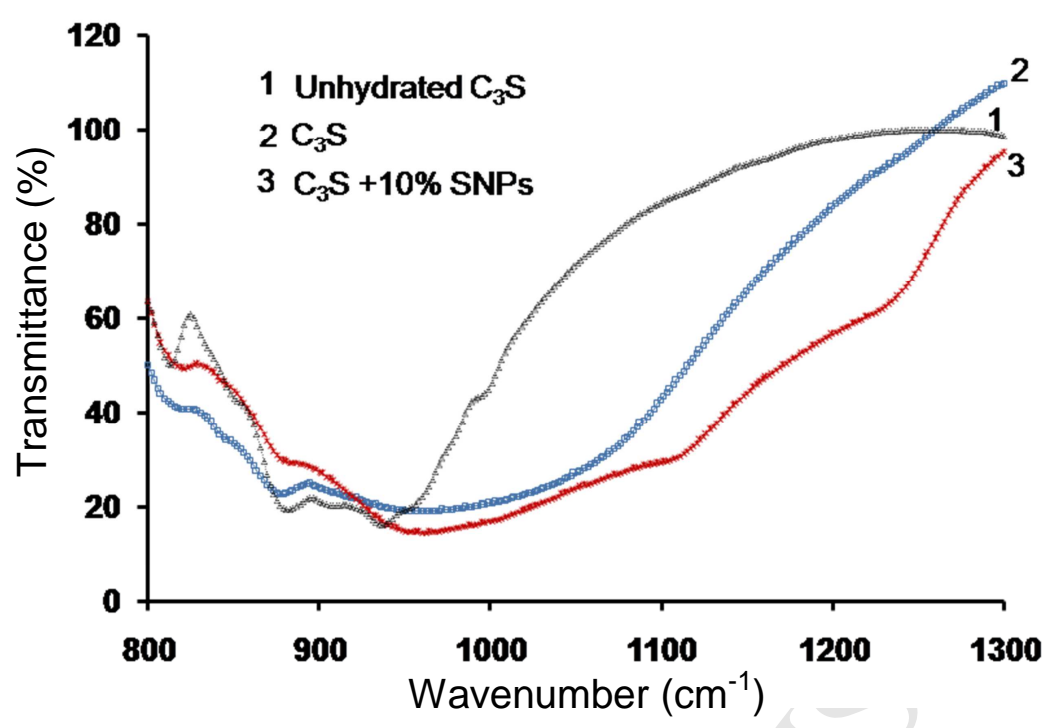

Fig. 9. FTIR of hydrated $\mathrm{C}_{3} \mathrm{~S}$ and SNPs incorporated $\mathrm{C}_{3} \mathrm{~S}$ at $24 \mathrm{~h}$.
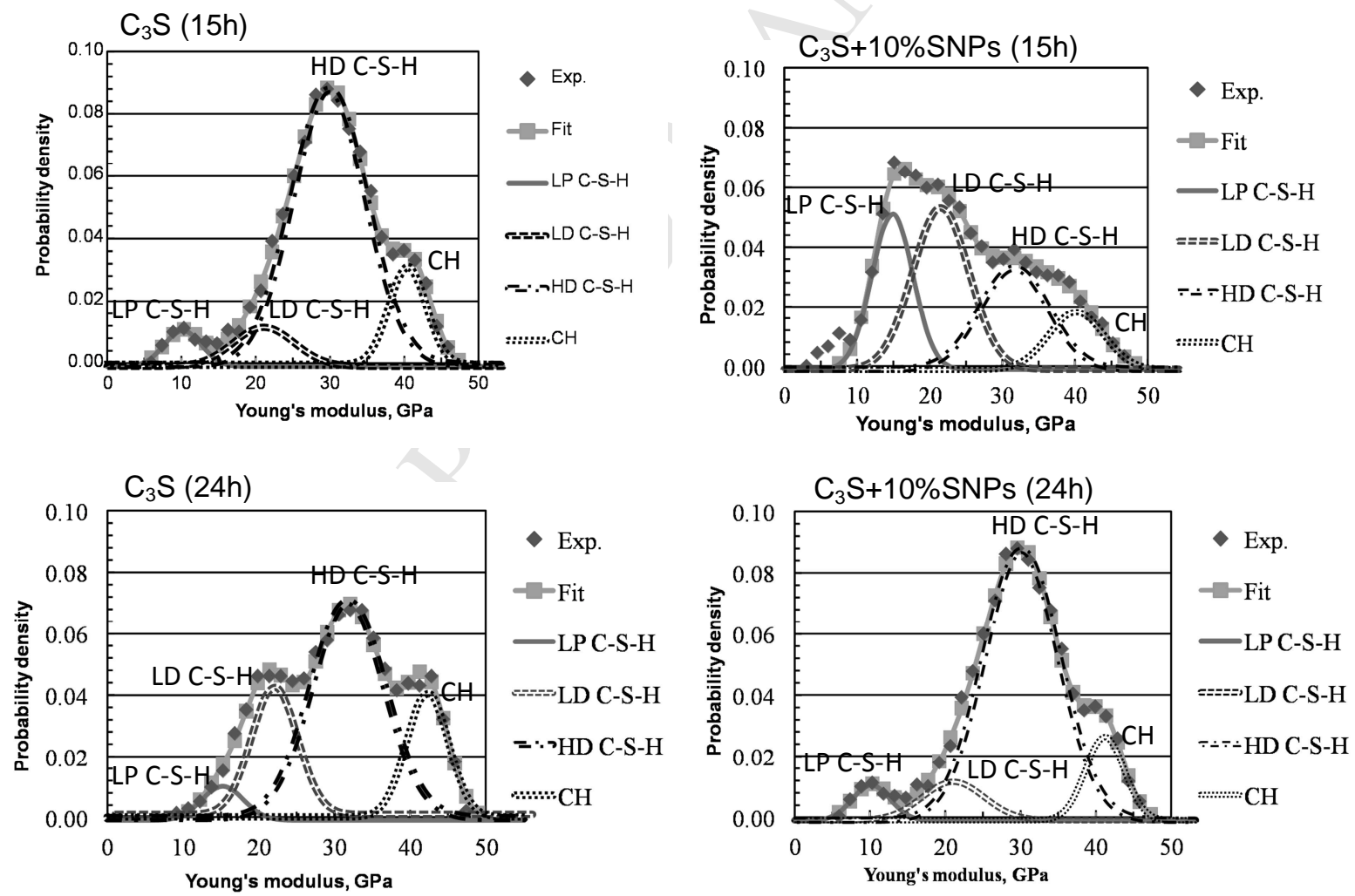

Fig. 10. Young's modulus histogram plots $(\mathrm{E}<50 \mathrm{GPa})$ with 4 Gaussian curves fitted, each representing one of the main hydrate phases. 

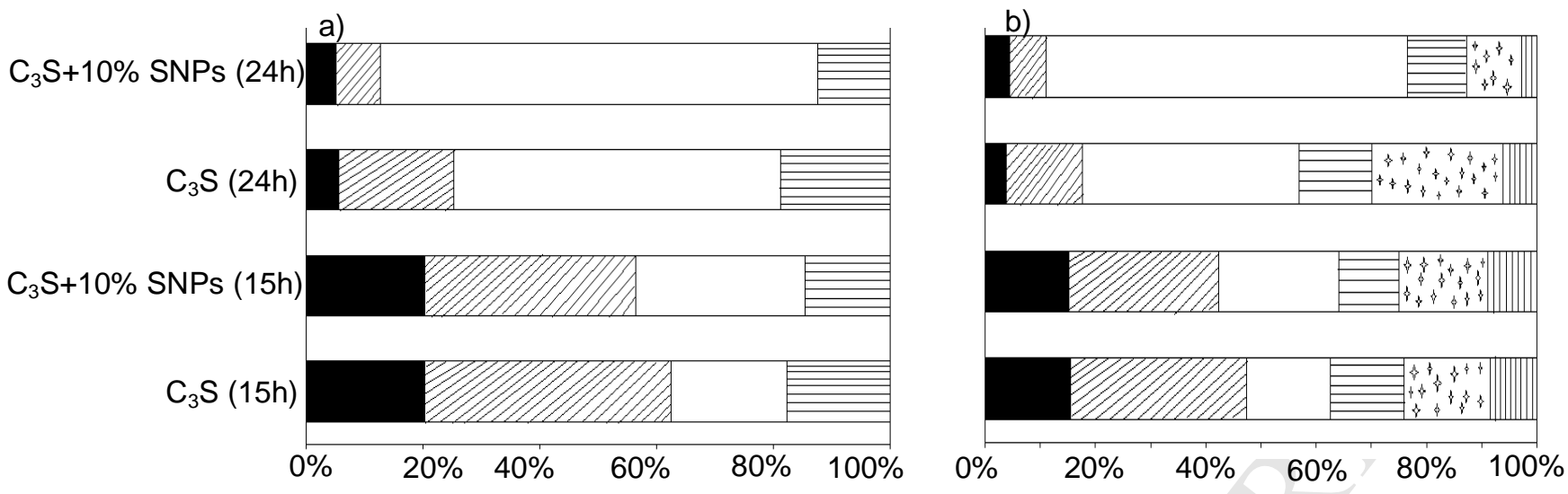

LP C-S-H LD C-S-H HD C-S-H $\quad \overline{\overline{C H}}_{\text {Partially hydrated clinker Unhydrated clinker }}^{\square}$

Fig.11. Phase contents plots for all pastes; a) relative phase content of the hydration phases; b) phase content of the full-range. 